Research Paper

\title{
Sphingosine kinase 1 mediates diabetic renal fibrosis via NF-кB signaling pathway: involvement of CK2 $2 \alpha$
}

\author{
Junying Huang ${ }^{1,2, *}$, Jingyan $\mathrm{Li}^{1, *}$, Zhiquan Chen ${ }^{1}$, Jie $\mathrm{Li}^{1}$, Qiuhong Chen ${ }^{1}$, Wenyan \\ Gong $^{1}$, Peiqing Liu ${ }^{1,3}$ and Heqing Huang ${ }^{1,3}$ \\ 1'Laboratory of Pharmacology \& Toxicology, School of Pharmaceutical Sciences, Sun Yat-sen University, Guangzhou 510006, \\ China \\ ${ }^{2}$ College of Life Sciences, Guangzhou University, Guangzhou 510006, China \\ ${ }^{3}$ National and Local United Engineering Lab of Druggability and New Drugs Evaluation, Guangzhou 51000, China \\ *These authors have contributed equally to this work \\ Correspondence to: Heqing Huang, email: huangheq@mail.sysu.edu.cn \\ Keywords: sphingosine kinase 1, casein kinase $2 \alpha$ subunit, diabetic nephropathy, NF- $k B$ pathway, renal fibrosis \\ Received: June 24, $2017 \quad$ Accepted: August 26, $2017 \quad$ Published: October 04, 2017 \\ Copyright: Huang et al. This is an open-access article distributed under the terms of the Creative Commons Attribution License \\ 3.0 (CC BY 3.0), which permits unrestricted use, distribution, and reproduction in any medium, provided the original author and \\ source are credited.
}

\section{ABSTRACT}

Sphingosine kinase 1 (SphK1) plays a pivotal role in regulating diabetic renal fibrotic factors such as fibronectin (FN) and intercellular adhesion molecule-1 (ICAM1). Especially, activation of SphK1 is closely linked to the body inflammatory reaction. Casein kinase $2 \alpha$ subunit (CK2 $\alpha$ ), a protein kinase related to inflammatory reaction, influences diabetic renal fibrosis and expressions of FN and ICAM-1 via NF-кB pathway. However, the mechanism by which SphK1 mediates diabetic renal fibrosis has not yet fully elucidated. The current study is aimed to investigate if SphK1 mediates diabetic renal fibrotic pathological process via inflammatory pathway and activation of CK2 $\alpha$. The following findings were observed: (1) Expressions of SphK1 were upregulated in kidneys of diabetic mice and rats; (2) Knockdown of SphK1 expression suppressed high glucose (HG)-induced NF-кB nuclear translocation and expressions of $F N$ and ICAM-1; (3) Compared with $\mathrm{C} 57$ diabetic mice, SphK1/- diabetic mice exhibited less renal fibrotic lesions, $\mathrm{FN}$ accumulation and NF- $\mathrm{KB}$ nuclear accumulation in glomeruli of kidneys; (4) SphK1 mediated phosphorylation of CK2 $\alpha$, while CK2 $\alpha$ knockdown depressed SphK1-induced activation of NF-кB pathway. This study indicates the essential role of SphK1 in regulating activation of CK2 $\alpha$ and diabetic renal fibrotic pathological process via NF-кB.

\section{INTRODUCTION}

Diabetic nephropathy (DN), also known as diabetic glomerulosclerosis characterized by renal fibrosis, is a major chronic microvascular complication of diabetes mellitus (DM) and is the leading cause of morbidity and mortality in diabetic patients with end-stage renal failure $[1,2]$. Accumulating evidence suggests that the pathological mechanism of diabetic renal fibrosis is complicated and closely related to numerous factors. Nonenzymatic glycation of proteins, glucolipid metabolism disorders, inflammation, oxidative stress, polyol pathway and MAPK signaling pathway are believed to be implicated in the development of diabetic renal fibrosis [3, 4]. However, the pathological mechanism of DN has not been fully elucidated. Increasing number of studies suggest that inflammation is involved in the development and progression of $\mathrm{DN}$, and it even receives serious attention that diabetic renal fibrotic disease is one kind of renal chronic inflammatory response [5-7]. NF$\kappa \mathrm{B}$, a classic inflammatory signaling pathway, regulates expressions of numerous genes regarding inflammatory response in the process of clinical and experimental kidney disease [8]. Five proteins have been found in the 
mammalian NF-кB family: RelA (p65), RelB, c-Rel, p50/p105 and p52/p100 [9]. Under non-diabetic state, $\mathrm{I} \kappa \mathrm{B}$ acts as an anchor protein to combine with $\mathrm{NF}-\kappa \mathrm{B}$ in the cytoplasm, forming an inactive complex to inhibit the activation of $\mathrm{NF}-\kappa \mathrm{B}$ signaling pathway. In response to stimulation, I $\kappa \mathrm{B}$ kinase (IKK) is phosphorylated and then phosphorylates $\mathrm{I} \kappa \mathrm{B}$ to cause ubiquitin-mediated degradation of $\mathrm{I} \kappa \mathrm{B}$ via proteasome, promoting release of $\mathrm{NF}-\kappa \mathrm{B}$ from inactive complex and then allowing $\mathrm{NF}-\kappa \mathrm{B}$ to translocate from cytoplasm into nucleus to trigger target genes expression $[10,11]$. Therefore, further study about the molecular mechanism of diabetic renal fibrosis and inflammation is imperative for preventing the progression of diabetic renal failure and exploring an approach to DN treatment.

Protein kinase CK2 (formerly casein kinase II), a highly conserved and ubiquitous second messengerindependent serine/threonine protein kinase, is widely distributed in the cytoplasm and nucleus of eukaryotic cells and phosphorylates more than 300 substrates to influence a vast array of biological and pathological processes [12]. CK2 $\alpha$, a catalytic subunit of CK2, has a significant serine/threonine kinase activity and even been considered to be significant in numerous key biological processes such as cell proliferation, differentiation and apoptosis [13-16]. What's more, CK2 $\alpha$ participates in development and progression of diseases including angiogenesis, glomerulonephritis, organogenesis and cancer [17-20]. Our previous study shows that activated $\mathrm{CK} 2 \alpha$ provokes inflammatory nuclear factor $\mathrm{NF}-\kappa \mathrm{B}$ through interacting with $\mathrm{I} \kappa \mathrm{B}$ to increase its degradation, upregulating expressions of inflammatory fibrotic factors including FN and ICAM-1 under diabetic state [21].

In recent years, the relationship between SphK1 and diabetic renal fibrosis also receives serious attention. SphK1 is activated under stimulation of advanced glycation end products (AGEs) or oxidative stress during the period of diabetes, accompanied by formation of S1P to mediate the biological and physiological activities of cells [22, 23]. Several studies demonstrate that sphingosine-1-phosphate (S1P), a lipid involved in cellular proliferation, is a phosphorylated product of sphingosine catalyzed by SphK1 and promotes cell proliferation of GMCs [24]. Moreover, activity of SphK1 and level of S1P are even upregulated in AGEs-cultured GMCs [25]. In vivo, compared with control groups, STZ-induced diabetic rats show higher activity of SphK1 and level of S1P in kidneys [26].

However, the mechanism by which SphK1 mediates diabetic renal fibrosis has not yet fully elucidated. It is reported that activity and protein level of SphK1 are upregulated in inflammation-related diseases [27-30]. Various inflammatory signals including interleukin $1 \beta$ (IL-1 $\beta$ ), interferon $\gamma$ (IF- $\gamma$ ) and lipopolysaccharide (LPS) promote SphK1 expression, indicating the underlying regulatory role of SphK1 on inflammatory reaction [31,
32]. It is also provided that renal inflammatory response in the context of DN is one of the important hallmarks of diabetic renal fibrosis, and $\mathrm{CK} 2 \alpha$ as well as SphK1 performs as a regulator in process of $\mathrm{DN}$. In view of these, it catches our interests whether SphK1-mediated diabetic renal pathological process via inflammatory pathway is dependent on activation of CK $2 \alpha$. In this study, we assessed the regulatory function of SphK1 on activation of NF $-\kappa \mathrm{B}$ and $\mathrm{CK} 2 \alpha$, and tried to explore the relationship between SphK1 and CK2 $\alpha$ in HG-induced GMCs and STZ-induced SphK $1^{-/}$diabetic mice.

\section{RESULTS}

\section{The expressions of SphK1 were upregulated in kidneys of diabetic animals}

Protein expressions of SphK1 were examined in kidneys of diabetic animals by western blotting. Compared with normal C57/BL6 mice, expressions of SphK1 were visibly upregulated in kidneys of spontaneous diabetic animals including $\mathrm{db} / \mathrm{db}$ diabetic mice and KKAy diabetic mice (Figure 1A \& 1B). Data further indicated that increases of SphK1 expression occurred in kidneys of STZ-induced C57/BL6 diabetic mice and SD diabetic rats by comparing with the control animals (Figure 1C \& 1D). The above results described here showed an essential link between SphK1 and DN.

\section{The activity and protein level of SphK1 were upregulated in high glucose-induced GMCs}

Data of immunofluorescence showed evident expression of SphK1 in the cytoplasm of GMCs (Figure 2A). To investigate the activation of SphK1 in GMCs during diabetes, activity and protein level of SphK1 were measured by LC-MS/MS and western blotting respectively. During continuous HG stimulation, protein level of SphK1 as well as renal fibrotic factors containing FN and ICAM-1 was upregulated in a time-dependent manner, reaching a peak value at $48 \mathrm{~h}$ (Figure 2B \& 2C). Similarly, activity of SphK was upregulated (Figure 2D), and fluorescent levels of FN and ICAM-1 improved after HG treatment for $48 \mathrm{~h}$ (Figure 2E \& 2F).

\section{Overexpression of SphK1 elevated expressions of FN and ICAM-1 in normal glucose-cultured GMCs}

For investigating the effect of SphK1 on inflammatory fibrotic factors FN and ICAM-1 further, plasmids of SphK1 G82D, a dominant negative SphK1 mutant, and wild-type SphK1 were overexpressed in normal glucose (NG)-cultured GMCs. Compared with the normal control, significant increases of FN and ICAM1 occurred in GMCs expressing wild-type SphK1 but 
not in cells expressing SphK1 G82D (Figure 3A \& 3C). Consistently, FN and ICAM-1 fluorescent levels improved in SphK1-overexpressed GMCs (Figure 3B \& 3D).

\section{Knockdown of SphK1 decreased expressions of FN and ICAM-1 in normal glucose-cultured GMCs}

The aforementioned data suggested overexpression of wild-type SphK1 abundantly augmented FN and ICAM1 protein levels, and we further measured expressions of FN and ICAM-1 in SphK1-silenced GMCs. Knockdown of SphK1 was in GMCs by the method of siRNA (Figure $4 \mathrm{~A}$ ), accompanied by decreases of FN and ICAM-1 in NG-cultured GMCs (Figure 4B). Moreover, knockdown of SphK1 reduced FN and ICAM-1 fluorescent levels in NG-cultured GMCs (Figure 4C \& 4D).

\section{Overexpression of SphK1 elevated nuclear translocation of NF- $\mathrm{KB}$ in normal glucose- cultured GMCs}

Upon HG stimulation for $30 \mathrm{~min}$, IкB dissociates from $\mathrm{NF}-\mathrm{\kappa B}$ to be degraded via proteasome, triggering nuclear translocation of free NF-KB to boost FN and ICAM-1 expressions in GMCs [11]. Since the above data revealed that activated SphK1 was implicated in expressions of FN and ICAM-1, we further examined activation of NF- $\mathrm{KB}$ in GMCs expressing wild-type SphK1 or SphK1 G82D. Overexpression of SphK1, as well as HG stimulation for $30 \mathrm{~min}$, improved nuclear NF- $\mathrm{kB}$ p65 protein level and decreased protein levels of cytoplasmic

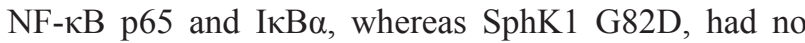
obvious effect on NF- $\mathrm{KB}$ nuclear translocation (Figure 5A-5C). Immunofluorescence assay was performed to illustrate that nuclear NF- $\mathrm{BB}$ p65 fluorescent level improved under HG stimulus or SphK1 overexpression (Figure 5D).

A

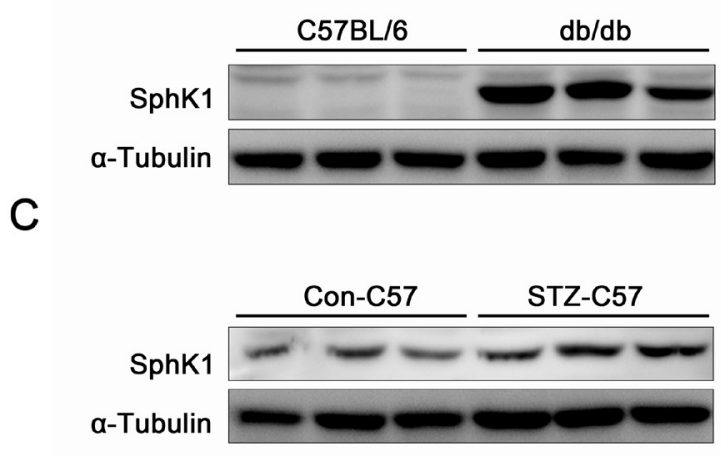

Knockdown of SphK1 decreased nuclear translocation of NF-kB in high glucose-induced GMCs

By the above experiment results, it was demonstrated that either SphK1 overexpression or HG stimulus provoked nuclear translocation of NF- $\mathrm{\kappa B}$ in GMCs. Simultaneously, knockdown of SphK1 even lowered nuclear NF- $\mathrm{kB}$ p65 protein level, increased cytoplasmic NF- $\kappa \mathrm{B}$ p65 protein level and occluded degradation of I $\mathrm{I} B \alpha$ in HG-treated GMCs (Figure 6A$6 \mathrm{C})$. Immunofluorescence assay was also carried out to illustrate that knockdown of SphK1 reduced HG-induced nuclear translocation of NF- $\mathrm{kB}$ in GMCs (Figure 6D).

\section{SphK1 ${ }^{-/}$diabetic mice exhibited less renal fibrotic lesions, FN accumulation and NF- $\mathrm{KB}$ nuclear accumulation in glomeruli of kidneys}

The in vitro experiments described here demonstrated that SphK1 exerted regulatory effects on nuclear transcriptional factor NF- $\mathrm{KB}$ as well as inflammatory fibrotic factors containing FN and ICAM1 in HG-induced GMCs. However, further work in vivo is required for elucidating the essential role of SphK1 in diabetic animals. Glomerular lesions in kidneys of STZ-induced C57 diabetic mice and SphK1 $1^{-/}$diabetic mice were detected, and data of hematoxylin-eosin (HE) stain and periodic acid-schiff (PAS) stain suggested that SphK1 $1^{-/}$diabetic mice exhibited less renal lesions such as extracellular matrix overexpression, mesangial area expansion, basement membrane thickening and adhesion arising between glomerulus and renal capsule than C57 diabetic mice, followed by reduced mesangial matrix index. Masson stain further indicated that decrease of collagenous fibers generation occurred in SphK $1^{--}$diabetic mice by comparing with $\mathrm{C} 57$ diabetic mice (Figure 7A \& 7B). Except for decrease of glomerular structural lesions,

B

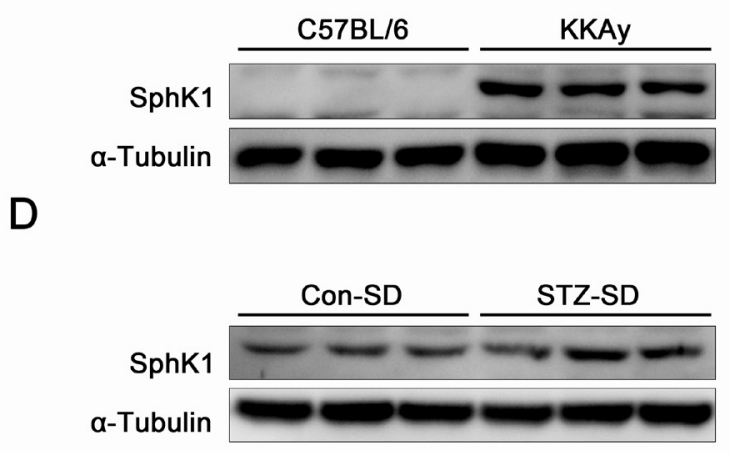

Figure 1: The expressions of SphK1 were upregulated in kidneys of diabetic animals. (A-D) The expressions of SphK1 in kidneys of $\mathrm{db} / \mathrm{db}$ diabetic mice, KKAy diabetic mice, STZ-induced C57 diabetic mice and STZ-induced SD rats were detected by western blotting ( $n=3$ different animals). 
$\mathrm{SphK}^{-/}$diabetic mice displayed less $\mathrm{FN}$ accumulation and NF- $\mathrm{NB}$ p 65 nuclear accumulation in glomeruli of kidneys versus C57 diabetic mice (Figure 7C \& 7D). Another detection by western blotting even showed that $\mathrm{NF}-\kappa \mathrm{B}$ p65 protein level increased in nuclear extract of

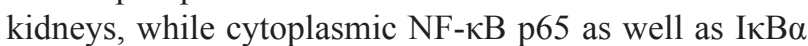
decreased in kidneys of C57 diabetic mice. Remarkably, $\mathrm{SphK}^{-/-}$diabetic mice showed less STZ-induced increase of nuclear NF- $\kappa \mathrm{B}$ p 65 and decrease of cytoplasmic NF$\kappa \mathrm{B}$ p65 as well as $\mathrm{I} \kappa \mathrm{B} \alpha$ than $\mathrm{C} 57$ diabetic mice (Figure 7E-7G). The above results pointed out a close correlation between SphK1 and DN, as well as activation of NF-кB.

A
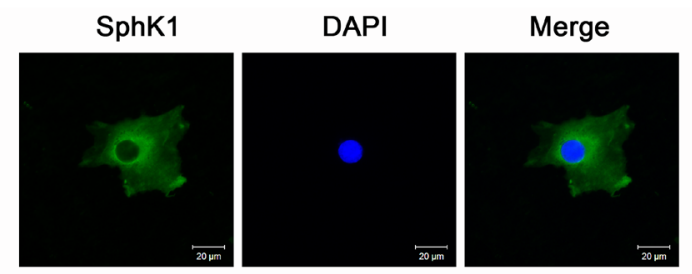

C

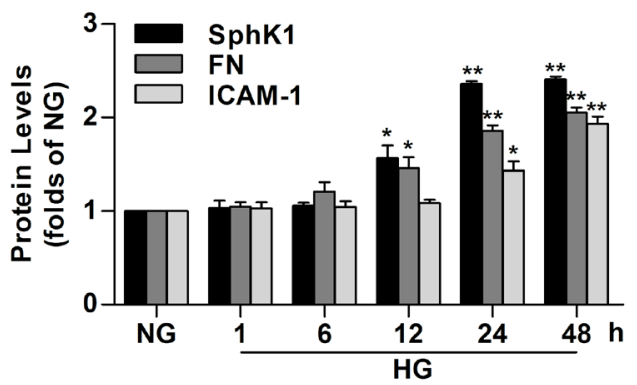

E

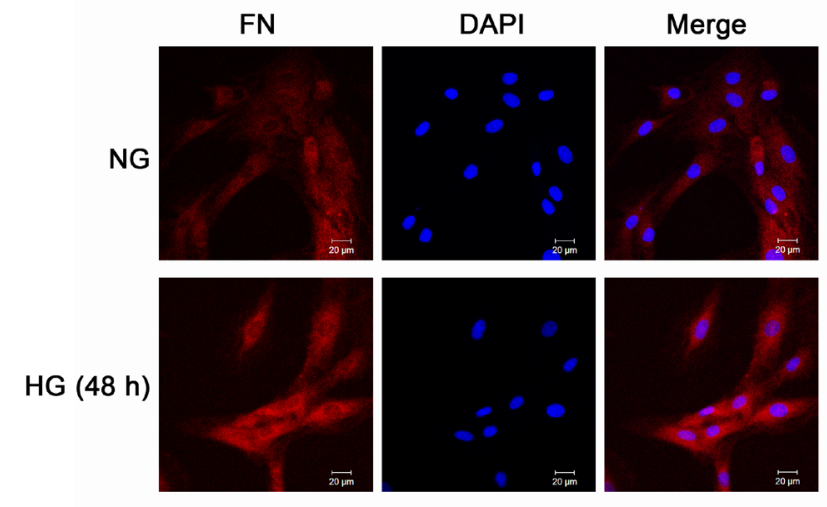

\section{Knockdown of CK2 $\alpha$ decreased nuclear translocation, transcriptional activity and DNA binding activity of NF- $\kappa B$ in SphK1- overexpressed GMCs}

Previous work and the above experiments established that SphK1 and CK2 $\alpha$ performed as important regulators on $\mathrm{FN}$ and ICAM-1expressions, as well as activation of NF- $\kappa \mathrm{B}$, suggesting that SphK1 and CK $2 \alpha$ were jointly implicated in the NF- $\kappa \mathrm{B}-$ mediated process of diabetic renal fibrosis. However, it remains unknown if there is a close interaction between SphK1 and CK2 $\alpha$,

B
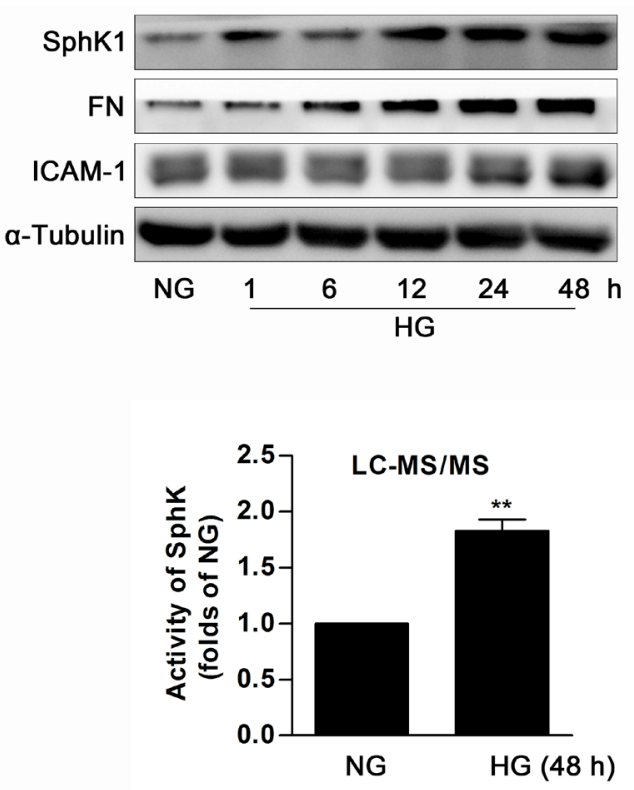

F

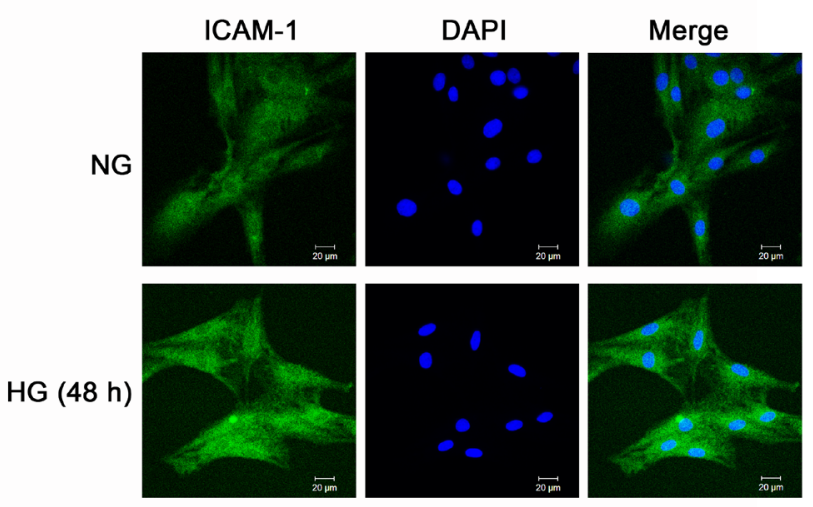

Figure 2: The activity and protein level of SphK1 were upregulated in high glucose-induced GMCs. (A) Immunofluorescent stain showed the subcellular distribution of SphK1 in NG-cultured GMCs. Green and blue stain respectively indicate SphK1 and nuclei. (B and C) Expressions of SphK1, FN and ICAM-1 were upregulated in $30 \mathrm{mM} \mathrm{HG-induced} \mathrm{GMCs} \mathrm{in} \mathrm{a} \mathrm{time-dependent} \mathrm{manner} \mathrm{(NG,} \mathrm{1,}$ $6,12,24,48$ h). Values represent means \pm S.E. ( $n=3$ independent experiments. ${ }^{*} \mathrm{P}<0.05,{ }^{* *} \mathrm{P}<0.01$ vs. NG by one-way ANOVA). (D) Activity of SphK was upregulated after treatment of high glucose for $48 \mathrm{~h}$ by LC-MS/MS. Values represent means \pm S.E. ( $n=3$ independent experiments. ${ }^{* *} \mathrm{P}<0.01$ vs. NG by Student's t test). ( $\mathbf{E}$ and $\left.\mathbf{F}\right)$ Fluorescent levels of FN and ICAM-1 improved by immunofluorescent stain. Blue, red and green stain respectively indicate nuclei, FN and ICAM-1. 
and what are associated to the regulatory mechanism. Results of western blotting and immunofluorescence indicated that knockdown of SphK1 caused no marked change on nuclear translocation of NF- $\mathrm{B}$ p 65 in $\mathrm{CK} 2 \alpha-$ overexpressed GMCs (Figure 8A \& 8C), whereas nuclear NF- $\kappa$ B p65 was extremely downregulated and cytoplasmic $\mathrm{NF}-\kappa \mathrm{B}$ p65 was improved after CK $2 \alpha$ knockdown in SphK1-overexpressed GMCs (Figure 8B \& 8D).

It was pointed out that $\mathrm{CK} 2 \alpha$ may be the downstream target protein of SphK1, and nuclear translocation of $\mathrm{NF}-\kappa \mathrm{B}$ was mediated by SphK1 via CK2 $\alpha$. We further investigated the role of $\mathrm{CK} 2 \alpha$ on transcription activity and DNA binding activity of NF- $\kappa \mathrm{B}$ in SphK1-induced GMCs by the methods of dual luciferase reporter assay and EMSA assay. Data described here indicated that knockdown of SphK1 failed to suppress transcriptional activity and DNA binding activity of NF- $\kappa \mathrm{B}$ in CK2 $\alpha$ overexpressed GMCs (Figure 8E \& 8G), but activation of $\mathrm{NF}-\kappa \mathrm{B}$ were effectively inhibited after CK2 $\alpha$ knockdown in SphK1-overexpressed GMCs (Figure 8F \& 8H).

\section{SphK1 mediated the activation of CK2 $\alpha$ in GMCs}

The aforementioned data indicated that CK2 $\alpha$ was required for SphK1-mediated activation of $\mathrm{NF}-\kappa \mathrm{B}$. To fully assess the regulatory function of SphK1 on CK2 $\alpha$ activity in GMCs, overexpressions of wild-type SphK1 and SphK1 G82D were applied to study phosphorylation of CK2 $\alpha$ at site of tyrosine 255, which was an indicator for CK2 $\alpha$ kinase activity [33]. Data showed that protein level of pTyr255 CK2 $\alpha$ was obviously upregulated after
A

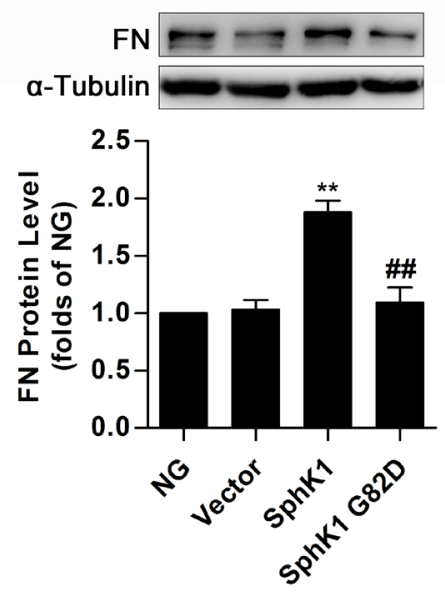

C

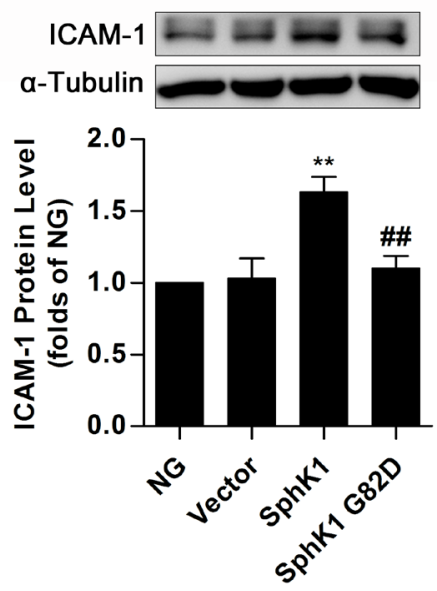

B

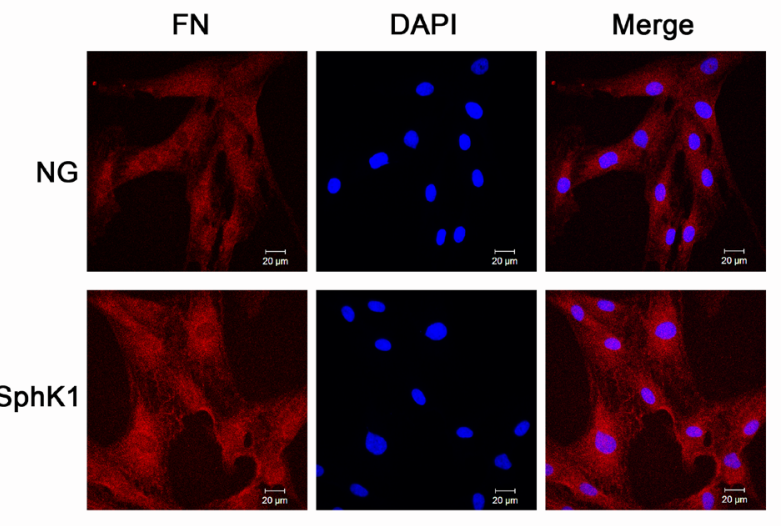

D

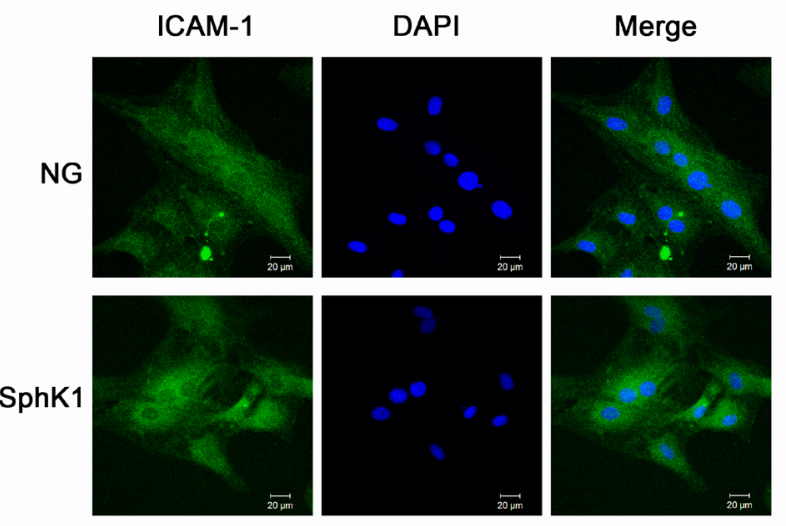

Figure 3: Overexpression of SphK1 elevated expressions of FN and ICAM-1 in normal glucose-cultured GMCs. (A and C) Data of western blotting showed that overexpression of wild-type SphK1, but not the dominant negative mutant SphK1 G82D, obviously increased expressions of FN and ICAM-1. Values represent means \pm S.E. $\left(n=3\right.$ independent experiments. ${ }^{* *} \mathrm{P}<0.01 \mathrm{vs}$. $\mathrm{NG}$; ${ }^{\#} \mathrm{P}<0.01$ vs. SphK1 by one-way ANOVA). (B and D) Fluorescent levels of FN and ICAM-1 improved by immunofluorescent stain after overexpression of wild-type SphK1. Blue, red and green stain respectively indicate nuclei, FN and ICAM-1. 
SphK1 overexpression in diabetic state or in non-diabetic state, whereas SphK1 G82D overexpression, had no effect on CK $2 \alpha$ activation (Figure 9A). Furthermore, knockdown of SphK1 suppressed protein level of pTyr255 CK2 $\alpha$ in HG-induced GMCs (Figure 9B).

PF-543, a competitive inhibitor to SphK1with an $\mathrm{IC}_{50}$ value of $3.6 \mathrm{nM}$ and $5 \mathrm{c}$, a non-competitive inhibitor to SphK1with an $\mathrm{IC}_{50}$ value of $3.3 \mu \mathrm{M}$, show inhibitory effect on enzyme activity of SphK1 [34-36]. MTT assay was applied to test cytotoxic effect of PF-543 and 5c in GMCs, suggesting that there were no evident inhibitory effect on cell growth when their concentrations were lower than 20 $\mu \mathrm{M}$ (Figure 9C \& 9D). $10 \mu \mathrm{M}$ of 5c suppressed activity of SphK1, followed by decrease of protein level of pTyr255 CK $2 \alpha$ in HG-induced GMCs, whereas $10 \mu \mathrm{M}$ of PF-543 which showed pharmacological inhibition on SphK1 like $5 c$, in contrast, failed to activate CK2 $\alpha$ (Figure 9E \& 9F).

\section{CK2 $\alpha$ interacted with SphK1 in GMCs}

Immunofluorescence and immunoprecipitation were performed to study the interaction of CK2 $\alpha$ and SphK1 in GMCs further. It was indicated by immunofluorescence that CK2 $\alpha$ and SphK1 showed visible cytoplasmic colocalization in GMCs which strengthened apparently after $30 \mathrm{~min}$ of HG treatment (Figure 10A). To further investigate the interaction between the two kinase, GMCs were lysed and total proteins were extracted for enrichment of CK2 $\alpha$ or SphK1 with target antibodies respectively. As shown in the co-immunoprecipitation and reverse co-immunoprecipitation results, CK2 $\alpha$ and SphK1 interacted with each other in NG condition and this interaction increased visibly after HG treatment in a time-dependent manner, reaching a peak value at $30 \mathrm{~min}$ (Figure 10B \& 10C).
A

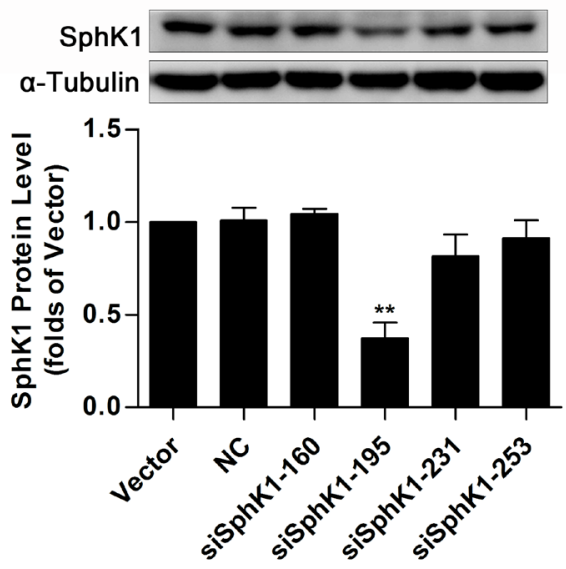

C

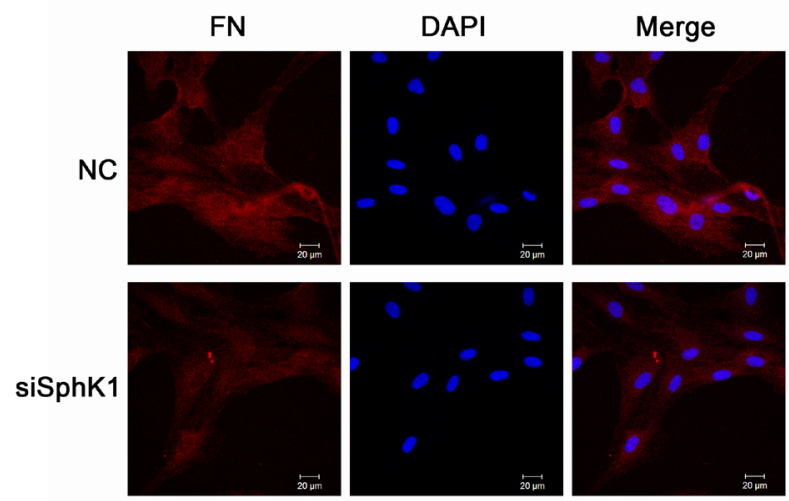

B

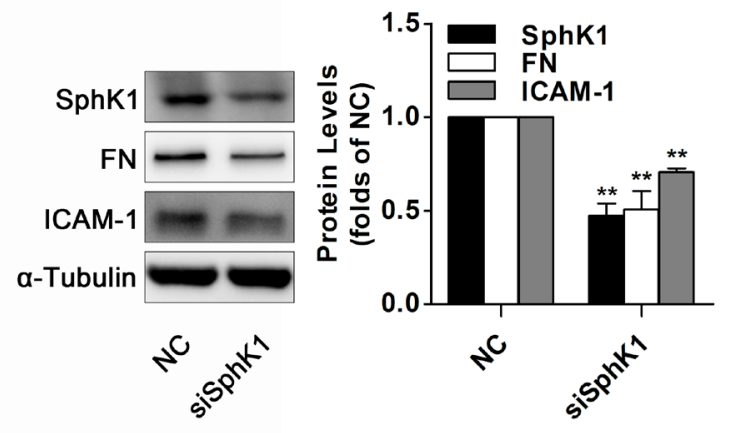

$\mathrm{D}$



Figure 4: Knockdown of SphK1 decreased expressions of FN and ICAM-1 in normal glucose- cultured GMCs. (A) Knockdown of SphK1 expression was detected by western blotting. GMCs were transfected with negative control or four pairs of siRNA oligonucleotides targeting SphK1 and then cultured for $48 \mathrm{~h}$. Values represent means \pm S.E. $\left(n=3\right.$ independent experiments. ${ }^{* *} \mathrm{P}<0.01 \mathrm{vs}$. Vector by one-way ANOVA). (B-D) Data from western blotting and immunofluorescent stain showed that knockdown of SphK1 reduced expressions of FN and ICAM-1 in GMCs. Blue, red and green stain respectively indicate nuclei, FN and ICAM-1. Values represent means \pm S.E. ( $n=3$ independent experiments. ${ }^{* *} \mathrm{P}<0.01$ vs. NC by Student's $t$ test). 


\section{DISCUSSION}

Previous studies suggest that SphK1 appears to act as an oncogenic enzyme regulating various processes which is important in cancer progression and even shows physiological regulatory functions on antiapoptosis, transformation, proliferation, and survival of tumor cells [37-39]. Accumulating evidence suggests that SphK1 is closely associated with inflammation, cardiovascular system and immune system, affecting diabetic nephropathy, angiogenesis, vascular maturation, smooth muscle cell proliferation and immune inflammatory regulation [40-42].

Elevated activity and expression of SphK1 have been observed in the development and progression of DN [22]. Activation of SphK1 induced by HG stimulation promotes S1P formation to trigger phosphorylation of c-Jun and c-Fos, which upregulates expressions of FN and TGF- $\beta 1$ and leads to diabetic renal fibrosis. AP- 1 , a dimer mainly formed by proteins of the Fos and Jun, is activated under HG stimulation and directly binds with its binding sites in SphK1 promoter to trigger SphK1 gene transcription, forming a positive feedback loop in diabetes [43]. In the current study, protein levels of SphK1 were significantly upregulated in kidneys of diabetic mice and rats. In vitro, SphK1 was activated and its protein level was significantly upregulated, accompanied by elevated expressions of FN and ICAM-1 in respond to HG stimulation. Furthermore, overexpression of exogenous SphK1 induced high expressions of FN and ICAM-1, while knockdown of SphK1 downregulated protein levels of FN and ICAM-1 in GMCs. In vivo, SphK1 has been considered to be a modulator on renal lesions, and FN is the major component of glomerular ECM, of which excessive generation performs as a dilapidator to provoke glomerular fibrotic lesions $[44,45]$. We demonstrated that SphK $1^{-/}$diabetic mice not only exhibited less generation of collagenous fibers and ECM, but also displayed less lesions and FN accumulation in glomeruli of kidneys than C57 diabetic mice.
A
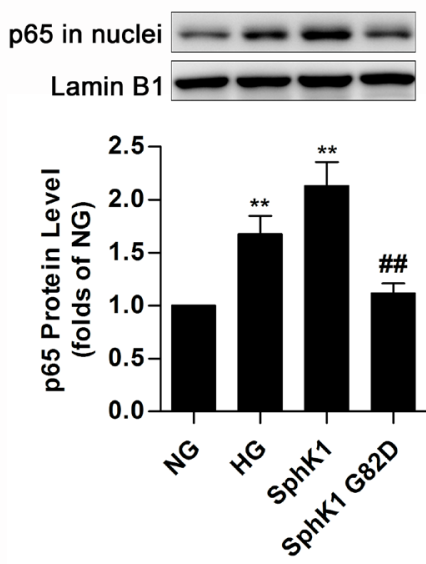

D
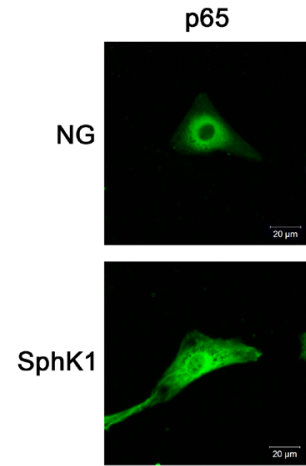

B

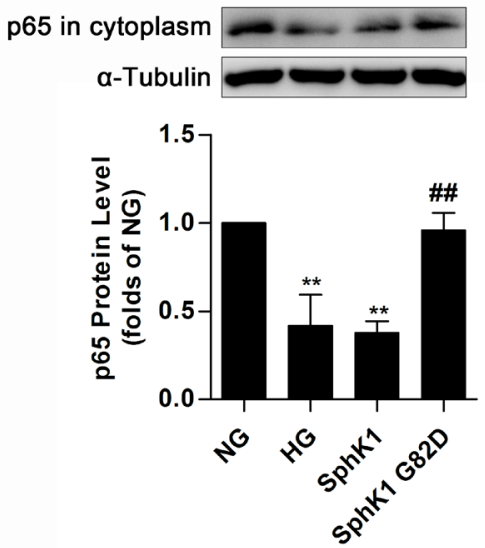

C 
In recent years, the correlation between SphK1 and DN has gradually become a hot topic, followed by an opinion that diabetic renal fibrotic disease is one kind of chronic inflammatory response in kidneys [5, 46]. SphK1 is also involved in the activation of several inflammatory responses during the regulation of cell physiological activities. Moreover, IL-1 $\beta$, IF- $\gamma$ and LPS induced inflammation via activating SphK1. Actually, process by which cyclooxygenase-2 (COX-2) induces inflammation under TNF- $\alpha$ treatment is inseparable from the activation of SphK1 [32, 47]. Notably, TNF- $\alpha$ stimulation activates SphK1 to increase expressions of VCAM-1 and ICAM1 , initiating formation of inflammatory infiltration around cells, which at last, leads to aggravate the situation of inflammation [48]. Data from Billich manifests that mRNA expression of SphK1 is upregulated in inflammation [49].

To further confirm the relationship between SphK1 and inflammation in the setting of DN, activation of NF$\kappa \mathrm{B}$ signaling pathway considered to be related to diabetic renal fibrosis was evaluated. As nuclear translocation of $\mathrm{NF}-\kappa \mathrm{B}$ is the main way of $\mathrm{NF}-\kappa \mathrm{B}$-related regulation on gene transcription, we demonstrated that overexpression of exogenous wild-type SphK1 but not SphK1 G82D augmented nuclear translocation of NF- $\mathrm{B}$ in GMCs. in vivo, $\mathrm{NF}-\kappa \mathrm{B}$ nuclear accumulation was upregulated in glomeruli of diabetic mice, but downregulated in SphK $1^{-1-}$ diabetic mice versus C57 diabetic mice. The in vivo and in vitro experiments basically confirmed the regulatory effect of SphK1 on NF- $\mathrm{BB}-$ mediated diabetic renal fibrosis.

$\mathrm{CK} 2 \alpha$, a crucial kinase involved in inflammation and cell proliferation, mediates activation of $\mathrm{NF}-\kappa \mathrm{B}$ by interacting with $\mathrm{I} \kappa \mathrm{B} \alpha$ in $\mathrm{HG}$-treated GMCs, which is a novel and important way for regulation on DN [21]. For investigating the regulatory mechanism between SphK1 and $\mathrm{CK} 2 \alpha$, activation of $\mathrm{NF}-\kappa \mathrm{B}$ was measured in GMCs including $\mathrm{NF}-\kappa \mathrm{B}$ nuclear translocation, transcriptional activity and DNA binding activity after overexpression of exogenous CK2 $\alpha$ while expression of SphK1 was knocked down by siRNA. As NF- $\mathrm{B}$ was activated by exogenous CK $2 \alpha$ overexpression, knockdown of SphK1 failed to block $\mathrm{CK} 2 \alpha$-induced $\mathrm{NF}-\kappa \mathrm{B}$ activation. By contrast, knockdown of CK2 $\alpha$ markedly suppressed SphK1-induced NF- $\kappa$ B activation, suggesting that CK $2 \alpha$ may be the downstream target protein of SphK1, and activation of NF- $\mathrm{NB}$ was mediated by SphK1 via CK $2 \alpha$ during DN.
A

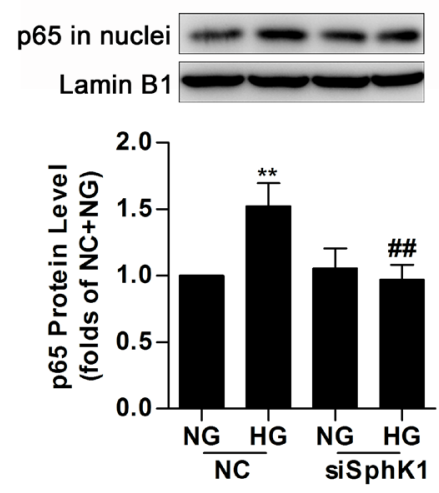

B

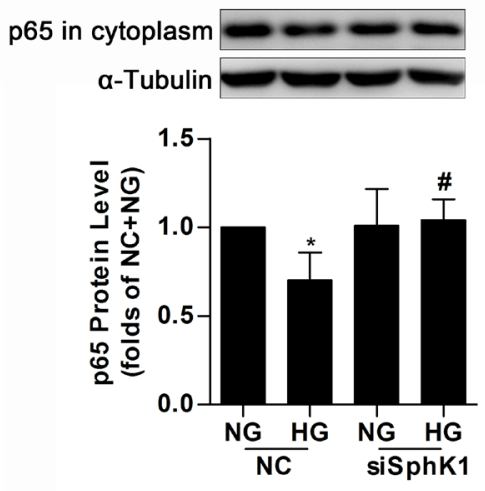

C

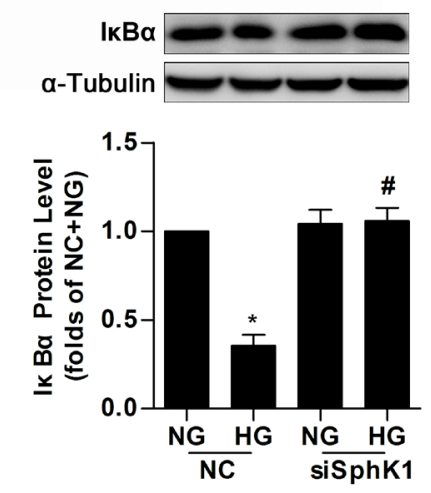

D
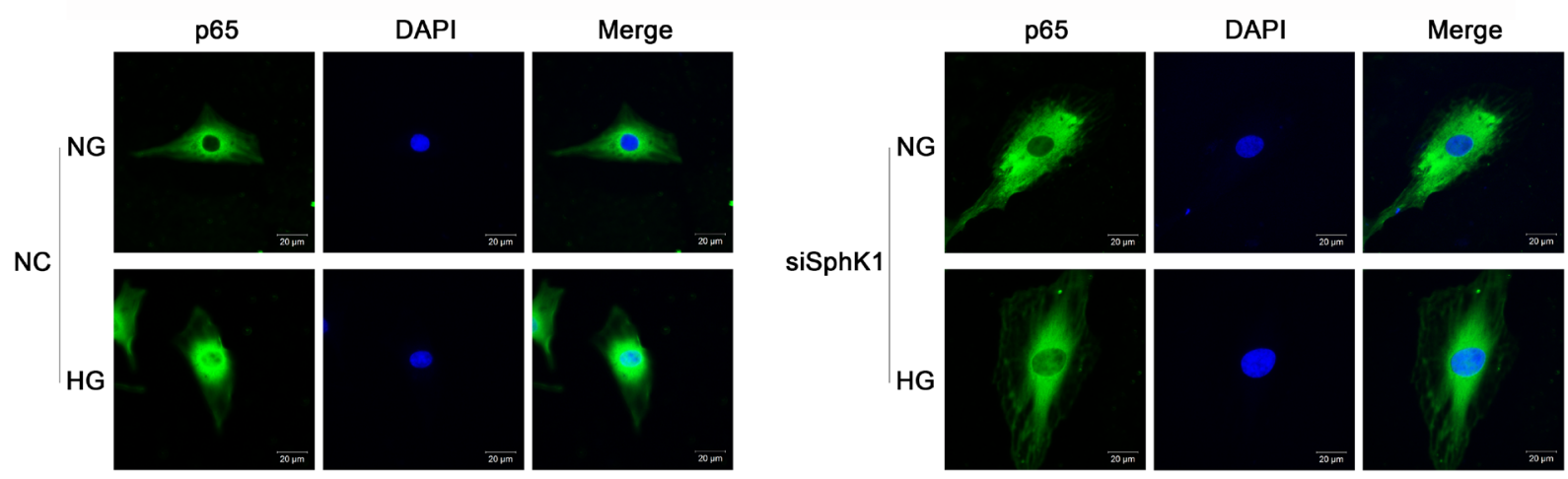

Figure 6: Knockdown of SphK1 decreased nuclear translocation of NF-кB in high glucose-induced GMCs. (A-C) HG

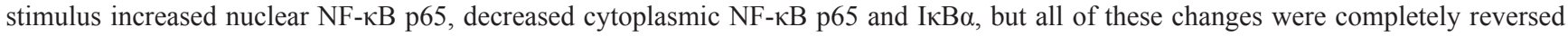
by knockdown of SphK1. Values represent means \pm S.E. $\left(n=3\right.$ independent experiments. ${ }^{*} \mathrm{P}<0.05,{ }^{* *} \mathrm{P}<0.01 \mathrm{vs}$. NC+NG; ${ }^{\mathrm{N}}<0.05$, ${ }^{\#} \mathrm{P}<0.01$ vs. $\mathrm{NC}+\mathrm{HG}$ by one-way ANOVA). (D) Impact of SphK1 knockdown on fluorescent level of NF-kB p65 were showed by immunofluorescent stain. Blue and green stain respectively indicate nuclei and NF- $\mathrm{BB}$ p65. 
A
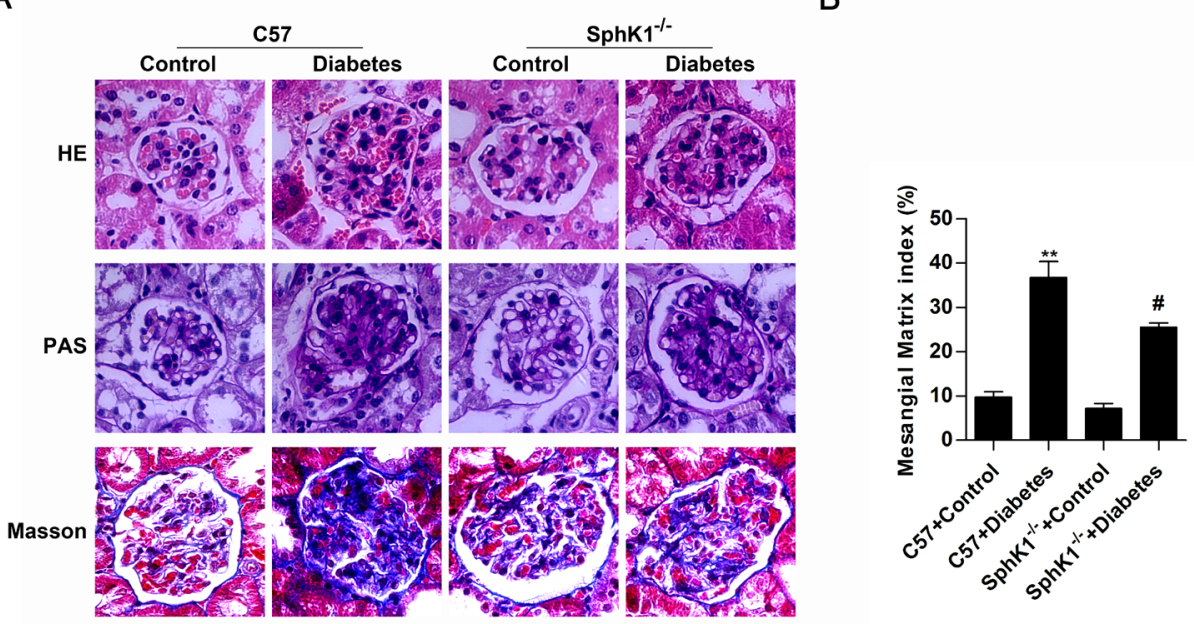

C



D



$\mathrm{E}$

$\mathrm{F}$

G
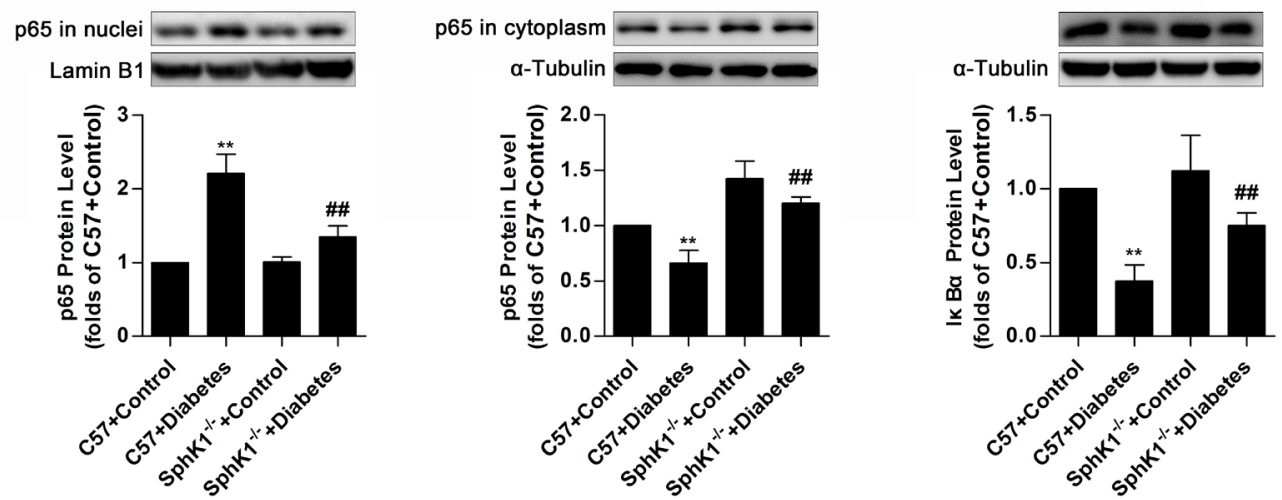

Figure 7: SphK1 ${ }^{-/-}$diabetic mice exhibited less renal fibrotic lesions, FN accumulation and NF- $\mathrm{KB}$ nuclear accumulation in glomeruli of kidneys. (A) Glomerular histopathology analysis of HE, PAS and Masson stain (400 $\times$ magnification) showed the renal lesions. Pictures displayed representative glomeruli in kidneys of mice. Green in Masson stain indicates collagenous fibers. (B) The pathological analysis of glomerular was performed using PAS stain (400 $\times$ magnification). Values represent means \pm S.E. $(n=3$ different mice. ${ }^{* *} \mathrm{P}<0.01$ vs. C57+Control; ${ }^{*} \mathrm{P}<0.05$ vs. C57+Diabetes by one-way ANOVA). (C and D) Immunohistochemical stain showed the expressions of SphK1, FN and nuclear NF- $\mathrm{BB}$ p65 in paraffin-embedded kidney tissues $(400 \times$ magnification $)$. Values represent means \pm S.E. $\left(n=3\right.$ different mice. ${ }^{* *} \mathrm{P}<0.01$ vs. C57+Control; ${ }^{* \#} \mathrm{P}<0.01$ vs. C57+Diabetes by one-way ANOVA). (E-G) Detached nuclear and cytoplasmic extracts from kidneys according to nuclear extract kit were subjected to western blotting for detection of nuclear NF- $\mathrm{BB}$


C57+Diabetes by one-way ANOVA). 

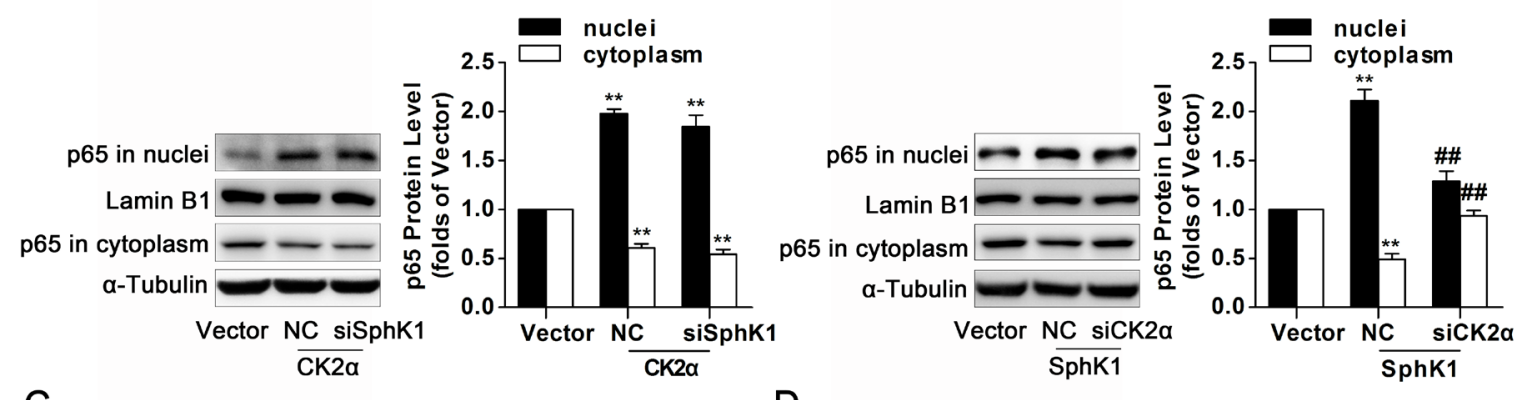

C
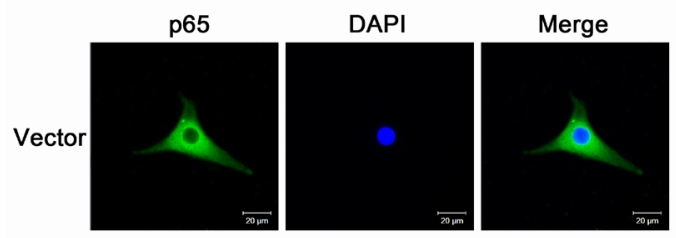

$\mathrm{D}$

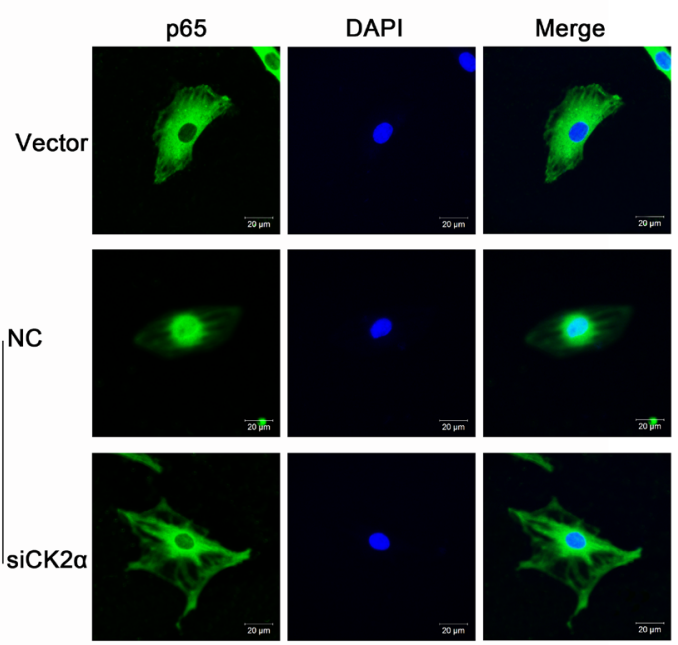

$\mathrm{E}$


G

$\mathrm{H}$

$\mathrm{F}$
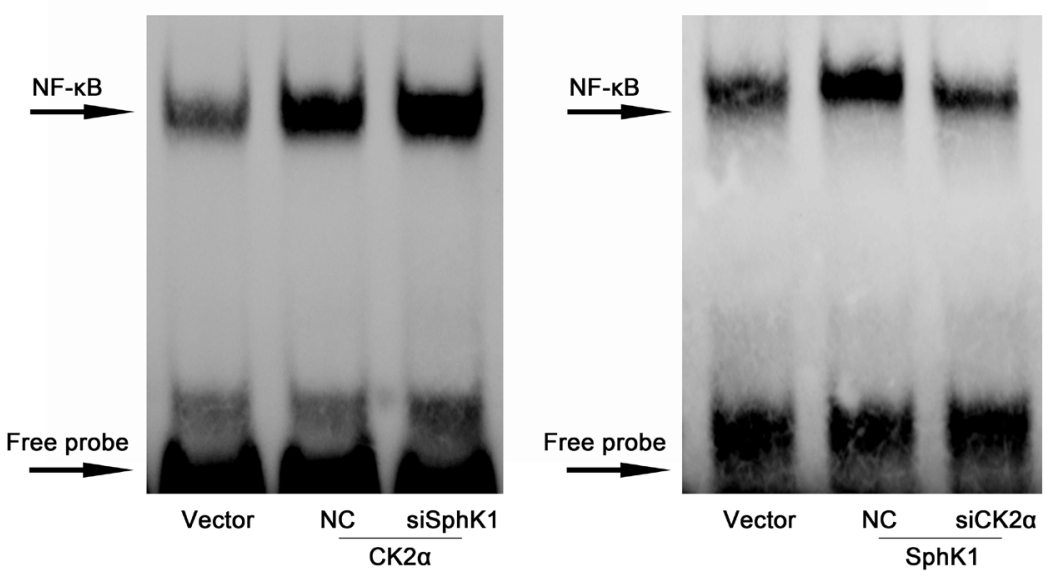

Figure 8: Knockdown of CK2 $\alpha$ decreased nuclear translocation, transcriptional activity and DNA binding activity of NF-KB in SphK1-overexpressed GMCs. (A and C) Data of western blotting and immunofluorescence showed that knockdown of SphK1 caused no evident change on nuclear translocation of NF- $\mathrm{KB}$ p65 in CK2 $\alpha$-overexpressed GMCs. Values represent means \pm S.E. $\left(n=3\right.$ independent experiments. ${ }^{* *} \mathrm{P}<0.01$ vs. Vector by one-way ANOVA). (B and D) However, nuclear NF-kB p65 was extremely downregulated and cytoplasmic NF-kB p65 was improved after CK2 $\alpha$ knockdown in SphK1-overexpressed GMCs. Values represent means \pm S.E. ( $n=3$ independent experiments. ${ }^{* *} \mathrm{P}<0.01$ vs. Vector; ${ }^{\# \#} \mathrm{P}<0.01$ vs. SphK $1+\mathrm{NC}$ by one-way ANOVA). (E-H) Transcriptional activity and DNA binding activity of NF- $\mathrm{kB}$ were effectively inhibited after CK2 $\alpha$ knockdown in SphK1-overexpressed GMCs, while knockdown of SphK1 showed no effective change on transcriptional activity and DNA binding activity of NF-KB in CK2 $\alpha$-overexpressed GMCs. Values represent means \pm S.E. $\left(~ n=3\right.$ independent experiments. ${ }^{* *} \mathrm{P}<0.01$ vs. Vector; ${ }^{*} \mathrm{P}<0.05$ vs. SphK1+NC by one-way ANOVA). 

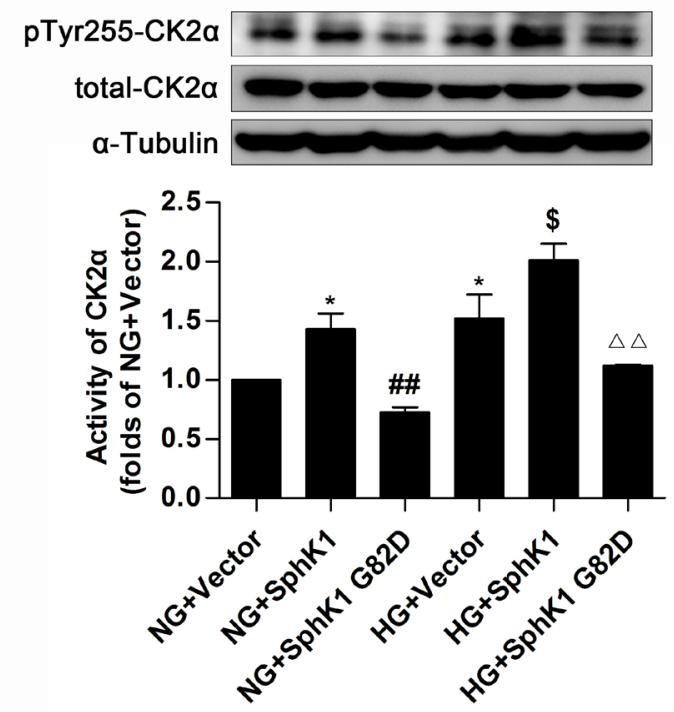

C

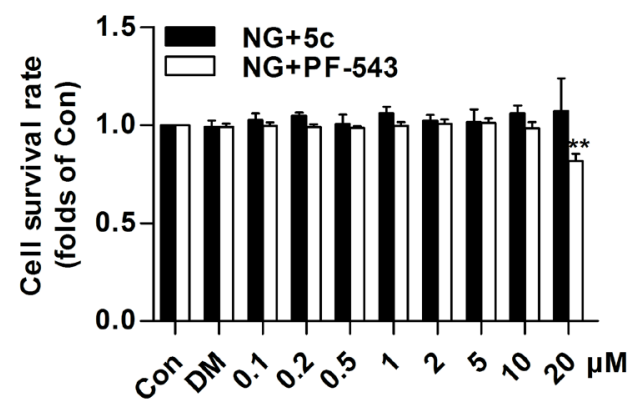

$E$

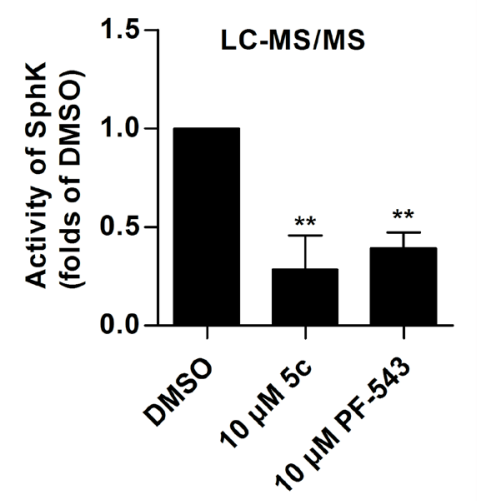

F
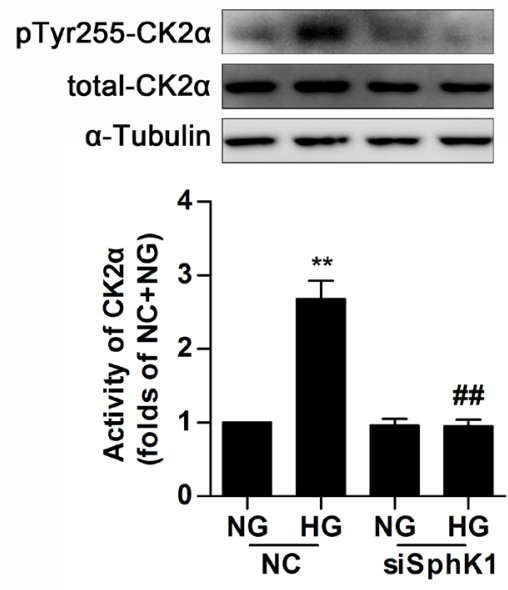

D



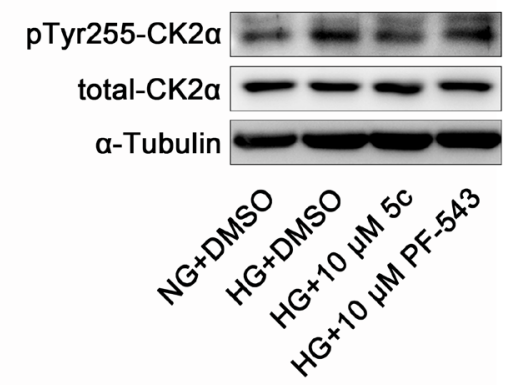

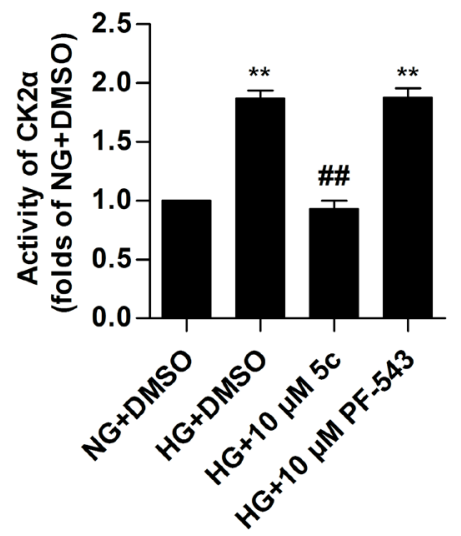

Figure 9: SphK1 mediated the activation of CK2 $\alpha$ in GMCs. (A and B) Protein level of pTyr255 CK2 $\alpha$ was upregulated after SphK1 overexpression in diabetic state or in non-diabetic state, while knockdown of SphK1 suppressed protein level of pTyr255 CK2 $\alpha$ in HG-induced GMCs. Values represent means \pm S.E. ( $n=3$ independent experiments. ${ }^{*} \mathrm{P}<0.05$ vs. NG+Vector;" $\mathrm{P}<0.01$ vs. NG+SphK1; ${ }^{5} \mathrm{P}$ $<0.05$ vs. HG+ Vector; ${ }^{\Delta} \mathrm{P}<0.01$ vs. HG+SphK1 by one-way ANOVA. ${ }^{* *} \mathrm{P}<0.01$ vs. $\mathrm{NC}+\mathrm{NG}$; ${ }^{* \prime} \mathrm{P}<0.01$ vs. NC+HG by one-way ANOVA). (C and D) MTT assay indicated effects of PF-543 or $5 \mathrm{c}$ on cell proliferation in a dose-dependent manner, and no obvious inhibitory effects were caused when their concentrations was lower than $20 \mu \mathrm{M}$ in NG or HG-cultured GMCs. Values represent means \pm S.E. $(n=3$ independent experiments. ${ }^{*} \mathrm{P}<0.05,{ }^{* *} \mathrm{P}<0.01$ vs. Con by one-way ANOVA). (E) $10 \mu \mathrm{M}$ of PF-543 or $5 \mathrm{c}$ apparently suppressed activity of SphK in GMCs by LC-MS/MS. Values represent means \pm S.E. ( $n=3$ independent experiments. ${ }^{* *} \mathrm{P}<0.01$ vs. DMSO by one-way ANOVA $)$. (F) $10 \mu \mathrm{M}$ of $5 \mathrm{c}$ suppressed protein level of pTyr255 CK2 $\alpha$ in HG-induced GMCs, but $10 \mu \mathrm{M}$ of PF-543 failed to do this. Values represent means \pm S.E. ( $n=3$ independent experiments. ${ }^{* *} \mathrm{P}<0.01$ vs. NG+DMSO; ${ }^{\# *} \mathrm{P}<0.01$ vs. HG+DMSO by one-way ANOVA). 
Results described in this study suggested that CK $2 \alpha$ and SphK1 interacted with each other in NG condition and this combination was stronger after $\mathrm{HG}$ treatment in a time-dependent manner, which not only pointed out the close interaction between CK2 $\alpha$ and SphK1 in the cytoplasm of GMCs, but also provided important evidence for regulation of SphK1 on CK2 $\alpha$ activation. Overexpression of wild-type SphK1 but not SphK1 G82D activated CK2 $\alpha$ in non-diabetic state, and activity of CK $2 \alpha$ further increased in SphK1-overexpressed GMCs upon HG stimulation. Remarkably, increase of CK2 $\alpha$ activity occurred in respond to $\mathrm{HG}$ treatment but declined after SphK1 knockdown. The above results indicated that activation of CK $2 \alpha$ induced by SphK1 may be an essential mechanism in CK2 $\alpha$-mediated diabetic renal fibrosis.

Previous studies have shown that SphK1 mediates downstream signaling pathways by catalyzing the phosphorylation of sphingosine to S1P, whereas substrates that can be directly phosphorylated by SphK1 are rarely reported $[50,51]$. Two selective inhibitors of SphK1 were performed to explore the phosphorylation of CK2 $\alpha$ by SphK1. PF-543, a competitive inhibitor and $5 \mathrm{c}$, a non-competitive inhibitor to SphK1 showed apparent inhibitory effect on enzyme activity of SphK1. As the phosphorylation level of CK2 $\alpha$ at the tyrosine site of 255 reflects its kinase activity, data suggested that 5c, but not PF-543, inhibited activation of CK $2 \alpha$ in $\mathrm{HG}$-induced GMCs, suggesting that $\mathrm{CK} 2 \alpha$ activation by SphK1 may not depend on generation of S1P. Unlike competition between PF-543 and sphingosine on binding sites of SphK1, 5c may inhibit phosphorylation and activation of CK2 $\alpha$ by binding SphK1 to inhibit its overall activity, and the process may not depend on the presence of S1P.

Taken together, the present study in vitro and in vivo demonstrated that SphK1 mediated pathological process of diabetic renal fibrosis via NF- $\kappa$ B pathway. SphK1 may be an upstream kinase of CK $2 \alpha$ and even phosphorylated

A

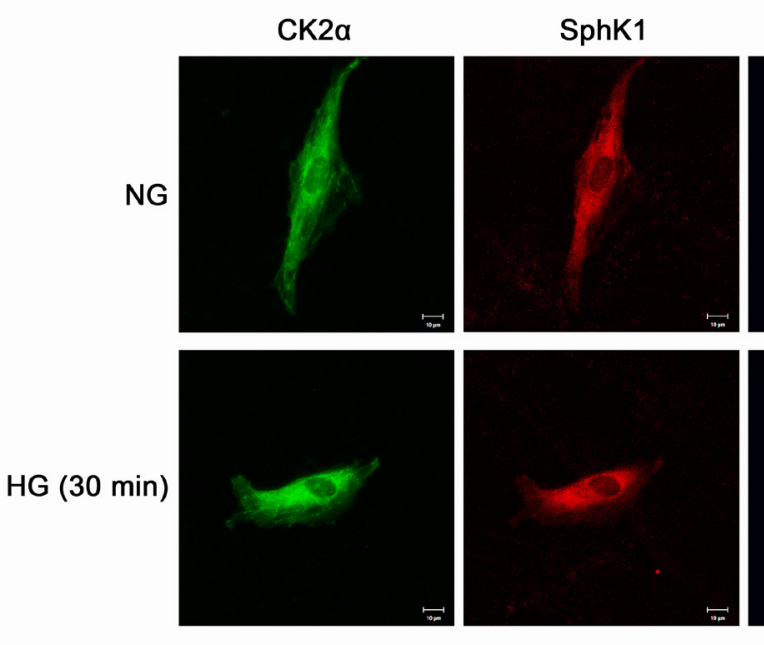

B

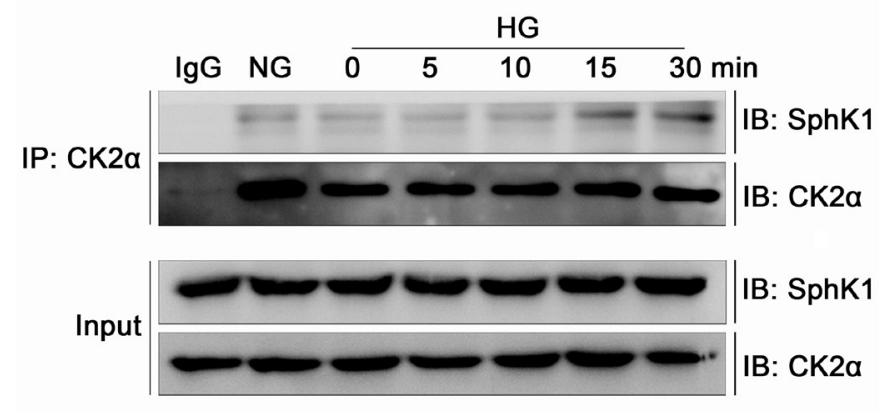

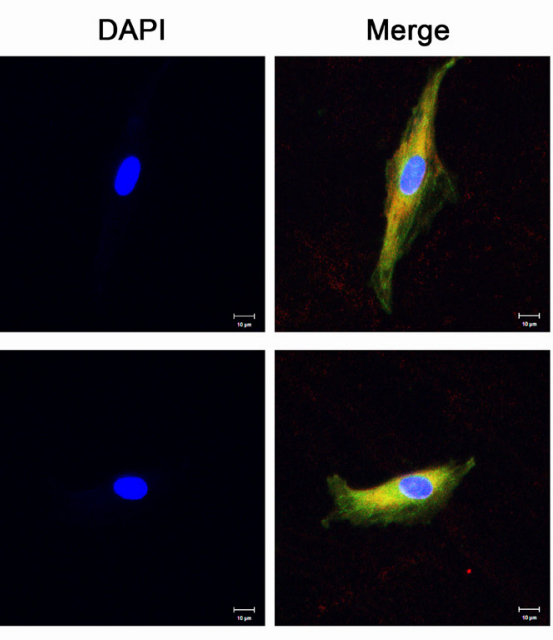

C

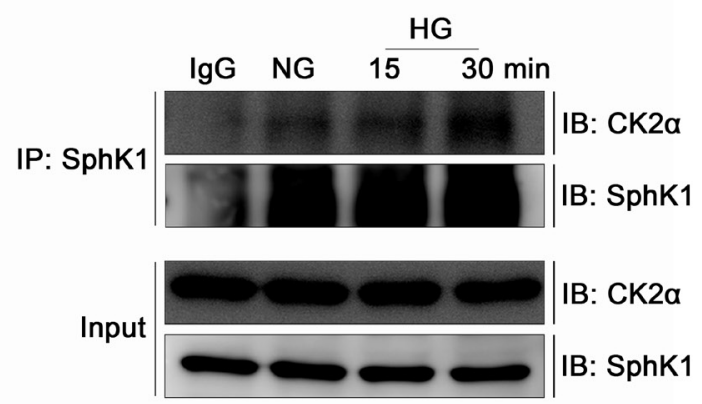

Figure 10: CK2 $\alpha$ interacted with SphK1 in GMCs. (A) It was indicated by immunofluorescence that CK2 $\alpha$ and SphK1 showed visible cytoplasmic co-localization in GMCs, which strengthened apparently after 30 min of HG treatment. (B and C) Co-immunoprecipitation and reverse co-immunoprecipitation assay were applied to detect the interaction between CK2 $\alpha$ with SphK1. This interaction reached a peak at $30 \mathrm{~min}$ after $\mathrm{HG}$ treatment. 
CK2 $\alpha$ to activate downstream NF- $\kappa$ B pathway. Further investigation will be needed to explore the detailed relationship between CK2 $\alpha$ and SphK1.

\section{MATERIALS AND METHODS}

\section{Reagents and antibodies}

Low glucose-Dulbecco's Modified Eagle Medium (DMEM), fetal bovine serum (FBS), RNAiMAX transfection reagent, LTX reagent with PLUS TM reagent and EMSA kit were purchased from Life Technologies (Grand Island, NY, USA). D-Glucose, antibody against pTyr255 CK2 $\alpha$, streptozotocin (STZ), thiazolyl blue tetrazolium bromide (MTT), dimethyl sulphoxide (DMSO) and ATP were obtained from Sigma-Aldrich Corporation (St. Louis, MO, USA). Antibodies against NF-kB p65, CK2 $\alpha$, Tubulin, Lamin B1 and SphK1 (antibody against SphK1 was used for western blotting, immunofluorescence and immunohistochemistry) were produced by Abcam (Cambridge, MA, USA). Antibodies against FN, ICAM-1, IкB $\alpha$ and SphK1 (antibody against SphK1 was only used for immunoprecipitation) were from Santa Cruz Biotechnology (Dallas, TX, USA). Flag-tagged human wild-type SphK1 and the dominant negative SphK1 (SphK1 G82D) were kindly provided by $\mathrm{Dr}$. Pu Xia (Australia). Horseradish peroxidaseconjugated secondary antibodies and Dual-Glo ${ }^{\circledR}$ Luciferase Assay System were obtained from Promega Corporation (Madison, WI, USA). Alexa Fluor $^{\circledR} 488$ goat anti-mouse IgG, Alexa Fluor ${ }^{\circledR} 488$ goat anti-rabbit IgG and Alexa Fluor ${ }^{\circledR} 594$ donkey anti-goat IgG were purchased from Thermo Fisher Scientific (Rockford, IL, USA). Nuclear extract kit was purchased from Active Motif (Carlsbad, CA, USA). The sequences on smallinterfering RNA of SphK1 or CK2 $\alpha$ were from Gene Pharma (Shanghai, China). SphK1 inhibitor 5c and S1P were obtained from Cayman Chemical Company (Ann Arbor, Michigan, USA). SphK1 inhibitor PF-543 was obtained from Selleck. C17-sph was purchased from Avanti Polar Lipids (Alabaster, AL, USA).

\section{Animal experiments}

All animals except SphK1/- mice (kindly provided by Richard L. Proia, NIH) were purchased from the Laboratory Animal Center, Sun Yat-sen University, Guangzhou, China, and housed under specific pathogenfree conditions. Procedures for animals treatment were implemented in accord with the China Animal Welfare Legislation and were reviewed and approved by the Sun Yat-sen University Committee on Ethics in the Care and Use of Laboratory. The mice and rats were adapted to the environments for one week before treatment. Fasting blood glucose (FBG) levels were detected, and mice with a value more than $11.1 \mathrm{mM}$ or rats with a value more than $16.7 \mathrm{mM}$ were regarded as diabetic models.
Animal Quality Certificate Number of male C57/ BL6 mice ( $\mathrm{n}=10,20 \pm 2 \mathrm{~g}), \mathrm{db} / \mathrm{db}$ mice $(\mathrm{n}=10,20 \pm 2$ g) and KKAy mice $(\mathrm{n}=10,20 \pm 2 \mathrm{~g})$ was 2014032122 . Experimental mice were divided into three groups as follows: C57 mice group $(\mathrm{n}=8), \mathrm{db} / \mathrm{db}$ mice group $(\mathrm{n}=$ 8), KKAy mice group $(\mathrm{n}=8)$.

Animal Quality Certificate Number of male C57/BL6 mice $(n=20,20 \pm 2 \mathrm{~g})$ was 20163000562 . One half of the mice were induced by intraperitoneal injection of freshly prepared STZ (40 mg/kg) in citrate buffer once a day for five consecutive days. Other ten of the mice were injected with an equal volume of citrate buffer. FBG levels of STZinduced mice were measured one week after STZ injection, and mice were divided into two groups as follows: C57 control group $(\mathrm{n}=8)$, diabetic mice group $(\mathrm{n}=8)$.

Animal Quality Certificate Number of male SD rats $(\mathrm{n}=20,180 \pm 10 \mathrm{~g})$ was 20164000744 . One half of the rats were induced by one single intraperitoneal injection of freshly prepared STZ $(40 \mathrm{mg} / \mathrm{kg})$ in citrate. Other ten of the rats were injected with an equal volume of citrate buffer. FBG levels of STZ-induced rats were measured one week after STZ injection, and rats were divided into two groups as follows: SD control group $(\mathrm{n}=8)$, diabetic rats group $(\mathrm{n}=8)$.

Animal Quality Certificate Number of male C57/ BL6 mice $(\mathrm{n}=20,20 \pm 2 \mathrm{~g})$ and SphK1 $1^{-/}$mice $(\mathrm{n}=20$, $20 \pm 2 \mathrm{~g}$ ) was 2014035372. One half of the C57 mice and SphK $1^{-/}$mice were induced by intraperitoneal injection of freshly prepared STZ $(40 \mathrm{mg} / \mathrm{kg})$ in citrate buffer once a day for five consecutive days. Others were injected with an equal volume of citrate buffer. FBG levels of STZinduced $\mathrm{C} 57$ mice and $\mathrm{SphK} 1^{-/}$mice were measured one week after STZ injection, and mice were divided into four groups as follows: C57 control group $(\mathrm{n}=8)$, C57 diabetic mice group $(\mathrm{n}=8)$, $\mathrm{SphK} 1^{-/}$control group $(\mathrm{n}=8), \mathrm{SphK} 1^{-/}$diabetic mice group $(\mathrm{n}=8)$.

Experimental animals were feed for eight weeks and were sacrificed, and kidney samples were collected for detection.

\section{Cell culture}

Primary GMCs were separated from SpragueDawley (SD) rats (around $150 \mathrm{~g}$ ) and identified via a specific assay as previously describe [25]. Cortex of kidneys were cut into pieces in ice-cold PBS, and the lumps were harvested to filtrate through three specific meshes orderly (sizes of meshes were 175, 147 and $74 \mu \mathrm{m})$. Ultimately, the matter upon $74 \mu \mathrm{m}$ mesh was collected, seeded in culture bottle and incubated in $10 \%$ FBS DMEM at $37^{\circ} \mathrm{C}$ with $5 \% \mathrm{CO}_{2}$ after digestion with $0.1 \%$ collagenase IV for 15-25 min. Passages of GMCs from 5th to 12th were used for experiments, and GMCs were rendered quiescent by incubation in serum-free medium for $24 \mathrm{~h}$ before treating with glucose or other stimuli while $80 \%$ confluent. 


\section{Western blot assay}

Western blot assay was performed with the standard protocol as previously described [52]. Cultured GMCs or kidney tissues were harvested and lysed for extracting proteins. RIPA with both protease and phosphatase cocktail was applied to extract total proteins, and nuclear extract kit was performed to extract nuclear and cytoplasmic proteins. Proteins from GMCs or tissues were separated by $8 \%$ sodium dodecyl sulfatepolyacrylamide gel electrophoresis (SDS-PAGE), and transferred to PVDF membrane for blocking with defatted milk at room temperature. Membranes with the target proteins were incubated at $4{ }^{\circ} \mathrm{C}$ with primary antibodies overnight. After incubation exceed $12 \mathrm{~h}$, membranes were washed with $0.1 \%$ Tween-20/TBS for three times in 30 min and incubated with the second antibodies at room temperature for $1 \mathrm{~h}$. Signals were recorded by ImageQuant LAS4000mini produced by GE healthcare (Waukesha, WI, USA) and analyzed by the Quantity One Protein Analysis Software produced from Bio-Rad Laboratories (Hercules, CA, USA).

\section{Immunofluorescence}

GMCs were seeded and cultured on glass coverslips for $24 \mathrm{~h}$ before treatment. After washing with icecold PBS for three times, GMCs were fixed with $4 \%$ paraformaldehyde for $15 \mathrm{~min}$ and then permeabilized with $0.1 \%$ Triton X-100 for $10 \mathrm{~min}$ at room temperature. After another washing with ice-cold PBS for three times, GMCs were blocked with $10 \%$ goat serum for $30 \mathrm{~min}$ and then incubated with primary antibodies overnight at $4{ }^{\circ} \mathrm{C}$. After incubation exceed $12 \mathrm{~h}$, GMCs were washed again and incubated with fluorescent secondary antibody for 1 $\mathrm{h}$ away from light at room temperature. 4',6-diamidino2-phenylindole (DAPI, Sigma, USA) was applied to stain nucleus for $10 \mathrm{~min}$. Fluorescent signals were recorded by a laser scanning confocal microscope (LSM710, Carl Zeiss, Germany).

\section{SphK activity assay}

SphK activity was measured via a specific assay as previously described. $2.5 \mu \mathrm{L}$ of $200 \mu \mathrm{M} \mathrm{C} 17-\mathrm{Sph}$ dissolved in $5 \%$ Triton X-100 and $2.5 \mu \mathrm{L}$ of $20 \mathrm{mM}$ ATP containing $200 \mathrm{mM} \mathrm{MgCl}$ were mixtured with $30 \mu \mathrm{g}$ proteins to a final volume of $50 \mu \mathrm{L}$. After incubation at $37^{\circ} \mathrm{C}$ for $20 \mathrm{~min}$, the reaction was terminated by adding with $5 \mu \mathrm{L}$ of $1 \mathrm{M} \mathrm{HCl}$ and $200 \mu \mathrm{L}$ of mix consisted of chloroform, methanol and $\mathrm{HCl}$ (100: 200: 1, v/v). $10 \mu \mathrm{L}$ of $1 \mu \mathrm{g} / \mathrm{mL} \mathrm{S1P}$, an internal standard for LC-MS/MS detection, was added into the reaction solution, and then $60 \mu \mathrm{L}$ of chloroform and $60 \mu \mathrm{L}$ of $2 \mathrm{M} \mathrm{KCl}$ were added. Oil and water phase were generated after centrifugation at $12,000 \mathrm{~g}$ for $5 \mathrm{~min}$ at $4{ }^{\circ} \mathrm{C}$, and then the oil phase was transferred into a $1.5 \mathrm{~mL}$ tube to vacuum-dry for 60 min. The residue was dissolved with mix consisted of methanol: $0.1 \%$ formic acid (95:5), and $10 \mu \mathrm{L}$ of solution was detected by LC-MS/MS system (Thermo Finnigan, Silicon Valley, CA, USA).

\section{Transfections of plasmids and small-interfering RNA}

Transfections of plasmids including Flag-tagged wild-type SphK1 and SphK1 G82D were applied to GMCs according to the manufacturer's instruction for LTX reagent with PLUSTM reagent. GMCs were cultured with $10 \%$ FBS DMEM for $24 \mathrm{~h}$ prior to transfection by which $2 \mu \mathrm{g}$ of plasmids was transfected into cells and then incubated for $48 \mathrm{~h}$ to harvest. Oligonucleotides targeting CK $2 \alpha$ or SphK1 for siRNA were produced from Gene Pharma, and the effective sequences were respectively as follows:

CK $2 \alpha$ forward: 5'-GCCAUCAAUAUCACA AAUATT-3';

CK $2 \alpha$ reverse: 5'-UAUUUGUGAUAUUG AUGGCTT-3';

SphK1 forward: 5'-GACGGCAACUCUAUUCUG UTT-3';

SphK1 reverse: 5'-ACAGAAUAGAGUUGCCGU CTT-3'.

The sequences for siRNA were transfected using RNAiMAX transfection reagent according to the manufacturer's protocol and then incubated with cells for $48 \mathrm{~h}$.

\section{Dual luciferase reporter assay}

GMCs were seeded and cultured in 96-well plates with $10 \%$ FBS DMEM for $24 \mathrm{~h}$ prior to treatment. 0.2 $\mu \mathrm{g}$ pNF-кB-Luc (Beyotime, Haimen, China) and $0.04 \mu \mathrm{g}$ pRL-TK (Promega) were co-transfected into GMCs using LTX reagent with PLUS ${ }^{\text {TM }}$ reagent for $48 \mathrm{~h}$ according to the manufacturer's instructions. Finally, cells were harvested and lysed, and luciferase activity of firefly or renilla were assessed according to Dual-Glo ${ }^{\circledR}$ Luciferase Assay System. Signals were normalized to the renilla luciferase activity.

\section{Electrophoretic mobility shift assay (EMSA)}

EMSA was performed to measure the DNA binding activity of NF- $\mathrm{KB}$ according to manufacturer's instruction. $5 \mu \mathrm{g}$ of nuclear proteins was incubated with the cocktail consisted of $50 \mathrm{ng} / \mathrm{ml}$ poly (dI-dC), $0.05 \%$ Nonidet P- 40 , $5 \mathrm{mM} \mathrm{MgCl}$ and $2.5 \%$ glycerol for $10 \mathrm{~min}$, and then incubated with NF- $\mathrm{\kappa B}$ probes for additional $20 \mathrm{~min}$ at room temperature. The samples were transferred to nylon membrane for DNA-protein crosslinks after separation by $7 \%$ nondenaturing PAGE. Membranes were blocked with blocking buffer for $1 \mathrm{~h}$ and incubated with horseradish peroxidase-conjugated streptavidin antibodies $(1: 300)$ for 
another $15 \mathrm{~min}$. Signals were visualized with enhanced chemiluminescence and recorded by ImageQuant LAS4000mini.

\section{MTT assay}

The MTT assay was used in measurement of cell proliferation according to protocol as previously described [52]. GMCs were seeded and cultured in 96well plates with $10 \%$ FBS DMEM for $24 \mathrm{~h}$ prior to treatment. Different concentrations of PF-543 or $5 \mathrm{c}$ were used to treat GMCs cultured in NG or HG condition in a dose-dependent manner. $0.5 \mathrm{mg} / \mathrm{mL}$ of MTT was added to each well and incubated with cells for $4 \mathrm{~h}$ prior to harvest. Medium of each well was abandoned, and then $100 \mu \mathrm{L}$ DMSO was added to dissolve crystal solid. The absorbance was detected and recorded at the wavelength of $570 \mathrm{~nm}$ by a microplate reader from Bio-Tek (Winooski, VT, USA).

\section{Immunoprecipitation}

GMCs were harvested and lysed with immunoprecipitation buffer on ice for $30 \mathrm{~min}$. Supernatant was collected after centrifuging at $12,000 \mathrm{~g}$ for $10 \mathrm{~min}$ at $4^{\circ} \mathrm{C}$, and $500 \mu \mathrm{g}$ of proteins was incubated with $2 \mu \mathrm{g}$ of antibodies against target protein or IgG overnight at $4^{\circ} \mathrm{C}$ keeping shaking. $30 \mu \mathrm{L}$ of agarose $\mathrm{A} / \mathrm{G}$ beads was added and incubated with the mixture for $4 \mathrm{~h}$ at $4^{\circ} \mathrm{C}$. After incubation, samples were washed three times with washing buffer and $25 \mu \mathrm{L}$ of SDS loading buffer was added to the bead-protein conjugate to mix. In the end, samples were subjected to western blot assay with respective antibodies.

\section{Statistical analysis}

All experiments were performed at least three times with similar results. Data were analyzed by Unpaired Student's $t$ test for comparison between two groups, and by one-way ANOVA with post hoc multiple comparisons for multiple comparisons. $\mathrm{P}<0.05$ was considered statistically significant.

\section{Abbreviations}

SphK1: sphingosine kinase 1; CK2 $\alpha$ : casein kinase $2 \alpha$ subunit; DN: diabetic nephropathy; DM: diabetes mellitus; ECM: extracellular matrix; FN: fibronectin; ICAM-1: intercellular adhesion molecule-1; NF- $\mathrm{B}$ : nuclear factor of kappa B; IкB: inhibitor of kappa B; IKK: inhibitor of kappa B kinase; GMCs: glomerular mesangial cells; NG: normal glucose; HG: high glucose; AGEs: advanced glycation end products; S1P: sphingosine-1phosphate; IL-1 $\beta$ : interleukin $1 \beta$; IF- $\gamma$ : interferon $\gamma$; LPS: lipopolysaccharide; TNF- $\alpha$ : tumor necrosis factor- $\alpha$; DMEM: Dulbecco's Modified Eagle Medium; FBS: fetal bovine serum; MTT: thiazolyl blue tetrazolium bromide;
DMSO: dimethyl sulphoxide; siRNA: small-interfering RNA; WB: western blotting; EMSA: electrophoretic mobility shift assay; LC-MS/MS: liquid chromatography tandem-mass spectrometry; FBG: fasting blood glucose; SD: Sprague-Dawley; STZ: streptozotocin; PAS: periodic acid-schiff; HE: hematoxylin-eosin.

\section{ACKNOWLEDGMENTS}

The authors thank Richard L. Proia (NIH) for providing SphK $1{ }^{--}$mice and Dr. Pu Xia (Australia) for providing flag-tagged human wild-type SphK1 and SphK1 G82D for this work

\section{CONFLICTS OF INTEREST}

The authors declare that there are no conflicts of interest.

\section{FUNDING}

This work was supported by research grants from the National Natural Science Foundation of China (Grant Numbers 81573477, 81373457), the subproject of National Science and Technology Major Project (Grant Number 2014ZX09301307-008), the Doctoral Program of the Ministry of Education of China (Grant number 20130171110097), the Natural Science Foundation Major Project of Guangdong Province (Grant Numbers 2017A030311036) and the Science and Technology Plan Project of Guangdong Province (Grant number 2015B090903063, 2014A020210007).

\section{REFERENCES}

1. Roscioni SS, Heerspink HJ, de Zeeuw D. The effect of RAAS blockade on the progression of diabetic nephropathy. Nat Rev Nephrol. 2014; 10:77-87.

2. Yang W, Lu J, Weng J, Jia W, Ji L, Xiao J, Shan Z, Liu J, Tian H, Ji Q, Zhu D, Ge J, Lin L, et al. Prevalence of diabetes among men and women in China. N Engl J Med. 2010; 362:1090-1101.

3. Sanchez AP, Sharma K. Transcription factors in the pathogenesis of diabetic nephropathy. Expert Rev Mol Med. 2009; 11:e13.

4. Kanwar YS, Wada J, Sun L, Xie P, Wallner EI, Chen S, Chugh S, Danesh FR. Diabetic nephropathy: mechanisms of renal disease progression. Exp Biol Med (Maywood). 2008; 233:4-11.

5. Chen X, Wu R, Kong Y, Yang Y, Gao Y, Sun D, Liu Q, Dai D, Lu Z, Wang N, Ge S, Wang F. Tanshinone IIA attenuates renal damage in STZ-induced diabetic rats via inhibiting oxidative stress and inflammation. Oncotarget. 2017; 8:31915-31922. https://doi.org/10.18632/oncotarget.16651. 
6. Wada J, Makino H. Inflammation and the pathogenesis of diabetic nephropathy. Clin Sci (Lond). 2013; 124:139-152.

7. Navarro-Gonzalez JF, Mora-Fernandez C, Muros DF, Garcia-Perez J. Inflammatory molecules and pathways in the pathogenesis of diabetic nephropathy. Nat Rev Nephrol. 2011; 7:327-340.

8. Nam JS, Cho MH, Lee GT, Park JS, Ahn CW, Cha BS, Lim SK, Kim KR, Ha HJ, Lee HC. The activation of NF-kappaB and AP-1 in peripheral blood mononuclear cells isolated from patients with diabetic nephropathy. Diabetes Res Clin Pract. 2008; 81:25-32.

9. Prabhu L, Mundade R, Korc M, Loehrer PJ, Lu T. Critical role of NF-kappaB in pancreatic cancer. Oncotarget. 2014; 5:10969-10975. https://doi.org/10.18632/oncotarget.2624.

10. Wang S, Yang Z, Xiong F, Chen C, Chao X, Huang J, Huang H. Betulinic acid ameliorates experimental diabeticinduced renal inflammation and fibrosis via inhibiting the activation of NF-kappaB signaling pathway. Mol Cell Endocrinol. 2016; 434:135-143.

11. Xie X, Peng J, Chang X, Huang K, Huang J, Wang S, Shen $\mathrm{X}$, Liu P, Huang H. Activation of RhoA/ROCK regulates NF-kappaB signaling pathway in experimental diabetic nephropathy. Mol Cell Endocrinol. 2013; 369:86-97.

12. Graczyk D, Debski J, Muszynska G, Bretner M, Lefebvre O, Boguta M. Casein kinase II-mediated phosphorylation of general repressor Mafl triggers RNA polymerase III activation. Proc Natl Acad Sci U S A. 2011; 108:4926-4931.

13. Schwind L, Wilhelm N, Kartarius S, Montenarh M, Gorjup E, Gotz C. Protein kinase CK2 is necessary for the adipogenic differentiation of human mesenchymal stem cells. Biochim Biophys Acta. 2015; 1853:2207-2216.

14. Zhou Y, Li K, Zhang S, Li Q, Li Z, Zhou F, Dong X, Liu L, Wu G, Meng R. Quinalizarin, a specific CK2 inhibitor, reduces cell viability and suppresses migration and accelerates apoptosis in different human lung cancer cell lines. Indian J Cancer. 2015; 52:e119-e124.

15. Zhang F, Yang B, Shi S, Jiang X. RNA interference (RNAi) mediated stable knockdown of protein casein kinase 2-alpha (CK2alpha) inhibits migration and invasion and enhances cisplatin-induced apoptosis in HEp-2 laryngeal carcinoma cells. Acta Histochem. 2014; 116:1000-1006.

16. St-Denis NA, Litchfield DW. Protein kinase CK2 in health and disease: from birth to death: the role of protein kinase CK2 in the regulation of cell proliferation and survival. Cell Mol Life Sci. 2009; 66:1817-1829.

17. Zhang X, Yang X, Yang C, Li P, Yuan W, Deng X, Cheng Y, Li P, Yang H, Tao J, Lu Q. Targeting protein kinase CK2 suppresses bladder cancer cell survival via the glucose metabolic pathway. Oncotarget. 2016; 7:87361-87372. https://doi.org/10.18632/oncotarget.13571.

18. Shi J, Liu N, Xiao Y, Takei Y, Yasue M, Suzuki Y, Hou Z, Ohno H, Yamada M, Fuchi N, Oshida K, Miyamoto Y, Tsujimoto G, Hirasawa A. The effects of a selective CK2 inhibitor on anti-glomerular basement membrane glomerulonephritis in rats. Biol Pharm Bull. 2015; 38:1345-1351.

19. Montenarh M. Protein kinase CK2 and angiogenesis. Adv Clin Exp Med. 2014; 23:153-158.

20. Lou DY, Dominguez I, Toselli P, Landesman-Bollag E, O'Brien C, Seldin DC. The alpha catalytic subunit of protein kinase CK2 is required for mouse embryonic development. Mol Cell Biol. 2008; 28:131-139.

21. Huang J, Chen Z, Li J, Chen Q, Li J, Gong W, Huang J, Liu P, Huang H. Protein kinase CK2alpha catalytic subunit ameliorates diabetic renal inflammatory fibrosis via NF-kappaB signaling pathway. Biochem Pharmacol. 2017; 132:102-117.

22. Chen C, Huang K, Hao J, Huang J, Yang Z, Xiong F, Liu P, Huang H. Polydatin attenuates AGEs-induced upregulation of fibronectin and ICAM-1 in rat glomerular mesangial cells and $\mathrm{db} / \mathrm{db}$ diabetic mice kidneys by inhibiting the activation of the SphK1-S1P signaling pathway. Mol Cell Endocrinol. 2016; 427:45-56.

23. Cho SY, Cho S, Park E, Kim B, Sohn EJ, Oh B, Lee EO, Lee HJ, Kim SH. Coumestrol suppresses hypoxia inducible factor 1alpha by inhibiting ROS mediated sphingosine kinase 1 in hypoxic PC-3 prostate cancer cells. Bioorg Med Chem Lett. 2014; 24:2560-2564.

24. Meyer ZH, Jakobs KH. Renal mesangial cells: moving on sphingosine kinase-1. Br J Pharmacol. 2007; 150:255-257.

25. Geoffroy K, Wiernsperger N, Lagarde M, El BS. Bimodal effect of advanced glycation end products on mesangial cell proliferation is mediated by neutral ceramidase regulation and endogenous sphingolipids. J Biol Chem. 2004; 279:34343-34352.

26. Geoffroy K, Troncy L, Wiernsperger N, Lagarde M, El BS. Glomerular proliferation during early stages of diabetic nephropathy is associated with local increase of sphingosine-1-phosphate levels. FEBS Lett. 2005; 579:1249-1254.

27. Geng T, Sutter A, Harland MD, Law BA, Ross JS, Lewin D, Palanisamy A, Russo SB, Chavin KD, Cowart LA. SphK1 mediates hepatic inflammation in a mouse model of NASH induced by high saturated fat feeding and initiates proinflammatory signaling in hepatocytes. J Lipid Res. 2015; 56:2359-2371.

28. Vettorazzi S, Bode C, Dejager L, Frappart L, Shelest E, Klassen C, Tasdogan A, Reichardt HM, Libert C, Schneider M, Weih F, Henriette UN, David JP, et al. Glucocorticoids limit acute lung inflammation in concert with inflammatory stimuli by induction of SphK1. Nat Commun. 2015; 6:7796.

29. Xu M, Liu D, Ding LH, Ma KL, Wu M, Lv LL, Wen Y, Liu H, Tang RN, Liu BC. FTY720 inhibits tubulointerstitial inflammation in albumin overload-induced nephropathy of rats via the Sphk1 pathway. Acta Pharmacol Sin. 2014; 35:1537-1545.

30. Liang J, Nagahashi M, Kim EY, Harikumar KB, Yamada A, Huang WC, Hait NC, Allegood JC, Price MM, Avni D, 
Takabe K, Kordula T, Milstien S, Spiegel S. Sphingosine1-phosphate links persistent STAT3 activation, chronic intestinal inflammation, and development of colitisassociated cancer. Cancer Cell. 2013; 23:107-120.

31. Fernandez-Pisonero I, Duenas AI, Barreiro O, Montero O, Sanchez-Madrid F, Garcia-Rodriguez C. Lipopolysaccharide and sphingosine-1-phosphate cooperate to induce inflammatory molecules and leukocyte adhesion in endothelial cells. J Immunol. 2012; 189:5402-5410.

32. Xia P, Gamble JR, Rye KA, Wang L, Hii CS, Cockerill P, Khew-Goodall Y, Bert AG, Barter PJ, Vadas MA. Tumor necrosis factor-alpha induces adhesion molecule expression through the sphingosine kinase pathway. Proc Natl Acad Sci U S A. 1998; 95:14196-14201.

33. Donella-Deana A, Cesaro L, Sarno S, Ruzzene M, Brunati AM, Marin O, Vilk G, Doherty-Kirby A, Lajoie G, Litchfield DW, Pinna LA. Tyrosine phosphorylation of protein kinase CK2 by Src-related tyrosine kinases correlates with increased catalytic activity. Biochem J. 2003; 372:841-849.

34. Ju T, Gao D, Fang ZY. Targeting colorectal cancer cells by a novel sphingosine kinase 1 inhibitor PF-543. Biochem Biophys Res Commun. 2016; 470:728-734.

35. Li ZH, Tao YF, Xu LX, Zhao H, Li XL, Fang F, Wu Y, Lu J, Li YH, Du WW, Ren JL, Li YP, Xu YY, et al. A novel sphingosine kinase 1 inhibitor (SKI-5C) induces cell death of Wilms' tumor cells in vitro and in vivo. Am J Transl Res. 2016; 8:4548-4563.

36. Wang J, Knapp S, Pyne NJ, Pyne S, Elkins JM. Crystal structure of sphingosine kinase 1 with PF-543. ACS Med Chem Lett. 2014; 5:1329-1333.

37. Datta A, Loo SY, Huang B, Wong L, Tan SS, Tan TZ, Lee SC, Thiery JP, Lim YC, Yong WP, Lam Y, Kumar AP, Yap CT. SPHK1 regulates proliferation and survival responses in triple-negative breast cancer. Oncotarget. 2014; 5:59205933. https://doi.org/10.18632/oncotarget.1874.

38. Guan H, Song L, Cai J, Huang Y, Wu J, Yuan J, Li J, Li M. Sphingosine kinase 1 regulates the Akt/FOXO3a/Bim pathway and contributes to apoptosis resistance in glioma cells. PLoS One. 2011; 6:e19946.

39. Shida D, Takabe K, Kapitonov D, Milstien S, Spiegel S. Targeting SphK1 as a new strategy against cancer. Curr Drug Targets. 2008; 9:662-673.

40. Ng ML, Wadham C, Sukocheva OA. The role of sphingolipid signalling in diabetesassociated pathologies (Review). Int J Mol Med. 2017; 39:243-252.

41. Lu Z, Zhang W, Gao S, Jiang Q, Xiao Z, Ye L, Zhang X. MiR-506 suppresses liver cancer angiogenesis through targeting sphingosine kinase 1 (SPHK1) mRNA. Biochem Biophys Res Commun. 2015; 468:8-13.

42. Lan T, Liu W, Xie X, Xu S, Huang K, Peng J, Shen X, Liu P, Wang L, Xia P, Huang H. Sphingosine kinase-1 pathway mediates high glucose-induced fibronectin expression in glomerular mesangial cells. Mol Endocrinol. 2011; 25:2094-2105.

43. Huang K, Huang J, Chen C, Hao J, Wang S, Huang J, Liu P, Huang H. AP-1 regulates sphingosine kinase 1 expression in a positive feedback manner in glomerular mesangial cells exposed to high glucose. Cell Signal. 2014; 26:629-638.

44. Cove-Smith A, Hendry BM. The regulation of mesangial cell proliferation. Nephron Exp Nephrol. 2008; 108:e74-e79.

45. Ichinose K, Kawasaki E, Eguchi K. Recent advancement of understanding pathogenesis of type 1 diabetes and potential relevance to diabetic nephropathy. Am J Nephrol. 2007; 27:554-564.

46. Duran-Salgado MB, Rubio-Guerra AF. Diabetic nephropathy and inflammation. 2014; 5:393-398.

47. Paugh BS, Bryan L, Paugh SW, Wilczynska KM, Alvarez SM, Singh SK, Kapitonov D, Rokita H, Wright S, Griswold-Prenner I, Milstien S, Spiegel S, Kordula T. Interleukin-1 regulates the expression of sphingosine kinase 1 in glioblastoma cells. J Biol Chem. 2009; 284:3408-3417.

48. Liu SQ, Su YJ, Huang JA, Qin MB, Tang GD. [Sphingosine kinase 1 enhances the proliferation and invasion of human colon cancer LoVo cells through up-regulating FAK pathway and the expression of ICAM-1 and VCAM-1]. [Article in Chinese]. Zhonghua Zhong Liu Za Zhi. 2013; 35:331-336.

49. Billich A, Bornancin F, Mechtcheriakova D, Natt F, Huesken D, Baumruker T. Basal and induced sphingosine kinase 1 activity in A549 carcinoma cells: function in cell survival and IL-1beta and TNF-alpha induced production of inflammatory mediators. Cell Signal. 2005; 17:1203-1217.

50. Pyne NJ, Ohotski J, Bittman R, Pyne S. The role of sphingosine 1-phosphate in inflammation and cancer. Adv Biol Regul. 2014; 54:121-129.

51. Orr GK, Obeid LM. Targeting the sphingosine kinase/ sphingosine 1-phosphate pathway in disease: review of sphingosine kinase inhibitors. Biochim Biophys Acta. 2013; 1831:157-166.

52. Jiang Q, Liu P, Wu X, Liu W, Shen X, Lan T, Xu S, Peng J, Xie X, Huang H. Berberine attenuates lipopolysaccharideinduced extracelluar matrix accumulation and inflammation in rat mesangial cells: involvement of NF-kappaB signaling pathway. Mol Cell Endocrinol. 2011; 331:34-40. 